\title{
Greenland ice sheet albedo feedback: thermodynamics and atmospheric drivers
}

\author{
J. E. Box ${ }^{1,2}$, X. Fettweis ${ }^{3}$, J. C. Stroeve ${ }^{4,5}$, M. Tedesco ${ }^{6}$, D. K. Hall ${ }^{7}$, and K. Steffen ${ }^{5}$ \\ ${ }^{1}$ Department of Geography, The Ohio State University, Columbus, OH, USA \\ ${ }^{2}$ Byrd Polar Research Center, The Ohio State University, Columbus, OH, USA \\ ${ }^{3}$ Department of Geography, University of Liège, Belgium \\ ${ }^{4}$ National Snow and Ice Data Center, Boulder, CO, USA \\ ${ }^{5}$ Cooperative Institute for Research in Environmental Sciences, University of Colorado, Boulder, CO, USA \\ ${ }^{6}$ The City University of New York, New York, NY, USA \\ ${ }^{7}$ NASA Goddard Space Flight Center, Greenbelt, MD, USA \\ Correspondence to: J. E. Box (box.11@osu.edu)
}

Received: 20 January 2012 - Published in The Cryosphere Discuss.: 13 February 2012

Revised: 14 May 2012 - Accepted: 28 June 2012 - Published: 8 August 2012

\begin{abstract}
Greenland ice sheet mass loss has accelerated in the past decade responding to combined glacier discharge and surface melt water runoff increases. During summer, absorbed solar energy, modulated at the surface primarily by albedo, is the dominant factor governing surface melt variability in the ablation area. Using satellite-derived surface albedo with calibrated regional climate modeled surface air temperature and surface downward solar irradiance, we determine the spatial dependence and quantitative impact of the ice sheet albedo feedback over 12 summer periods beginning in 2000. We find that, while albedo feedback defined by the change in net solar shortwave flux and temperature over time is positive over $97 \%$ of the ice sheet, when defined using paired annual anomalies, a second-order negative feedback is evident over $63 \%$ of the accumulation area. This negative feedback damps the accumulation area response to warming due to a positive correlation between snowfall and surface air temperature anomalies. Positive anomaly-gauged feedback concentrated in the ablation area accounts for more than half of the overall increase in melting when satellitederived melt duration is used to define the timing when net shortwave flux is sunk into melting. Abnormally strong anticyclonic circulation, associated with a persistent summer North Atlantic Oscillation extreme since 2007, enabled three amplifying mechanisms to maximize the albedo feedback: (1) increased warm (south) air advection along the western ice sheet increased surface sensible heating that in turn
\end{abstract}

enhanced snow grain metamorphic rates, further reducing albedo; (2) increased surface downward shortwave flux, leading to more surface heating and further albedo reduction; and (3) reduced snowfall rates sustained low albedo, maximizing surface solar heating, progressively lowering albedo over multiple years. The summer net infrared and solar radiation for the high elevation accumulation area approached positive values during this period. Thus, it is reasonable to expect $100 \%$ melt area over the ice sheet within another similar decade of warming.

\section{Introduction}

Greenland ice sheet mass balance fluctuations exert an important influence on global sea level, while changes to its cryosphere provide useful indicators of climate change. Between 1961 and 1990, a period in which the Greenland ice sheet was in relative balance (Rignot et al., 2008), the annual net snow accumulation totaled $\sim 700 \mathrm{Gt} \mathrm{yr}^{-1}$, balanced by $\sim 480 \mathrm{Gt} \mathrm{yr}^{-1}$ glacier discharge and $\sim 220 \mathrm{Gt} \mathrm{yr}^{-1}$ runoff losses (Ettema et al., 2009; van den Broeke et al., 2009). Subsequently, satellite gravimetry reveals overall mass loss (Chen et al., 2011) due to a combination of increased surface melting (Mote, 2007; Fettweis et al., 2011a) and runoff (Box et al., 2006; Ettema et al., 2009), peripheral dynamic thinning (Krabill et al., 2004; Pritchard et al., 2009) and increased 
glacier discharge (Rignot et al., 2006; Howat et al., 2008). During summer, absorbed solar energy (a.k.a. net shortwave flux), modulated at the surface primarily by albedo, is the dominant factor governing surface melt variability in the ablation area (van den Broeke et al., 2008). The current mass loss appears to be dominated by either ice discharge or surface ablation depending on which mass flux is greatest in a given year (Rignot et al., 2006; van den Broeke et al., 2009).

Changes in snow and ice cover duration and area have an amplifying effect on climate in warming and cooling scenarios from the complex and self-reinforcing surface albedo feedback with temperature. Hall (2004) reviews numerous relevant publications of the prior decades. Warming reduces albedo even without removing snow or ice cover, through the increase of snow grain size from snow crystal metamorphism (Wiscombe and Warren, 1980; Dozier et al., 2009; Warren, 1982). The feedback operates in reverse with cooling associated with higher albedo from more persistent snow cover, lower rain to snowfall ratios, and less positive surface radiation budget.

An assessment of Northern Hemispheric satellite and regional climate model data (Flanner et al., 2011) derives top of the atmosphere ice-albedo feedback magnitudes between 0.3 and $1.1 \mathrm{~W} \mathrm{~m}^{-2} \mathrm{~K}^{-1}$. Fernandes et al. (2009) measured surface albedo sensitivity to surface air temperature $\left(T_{\text {air }}\right)$ for land surfaces poleward of $30^{\circ} \mathrm{N}$ to be $-0.93 \pm 0.06 \% \mathrm{~K}^{-1}$ with maximum albedo sensitivity exceeding $-9 \% \mathrm{~K}^{-1}$ over the northern terrestrial environments where the albedo difference between snow cover and bare land reaches maximum values up to $\sim 0.7$. This study did not explicitly analyze albedo sensitivity for the Greenland ice sheet, presumably because downscaling would have been necessary to resolve the ice sheet ablation area.

Stroeve (2001) assessed Greenland ice sheet albedo variability using monthly averaged albedo from the AVHRR Polar Pathfinder (APP) data set spanning 1981-1998, finding (1) anomalously low albedo during the warm years of 1995 and 1998; (2) high albedo in 1992, associated with the low temperature anomaly caused by the Mt. Pinatubo eruption (e.g. Abdalati and Steffen, 2001); (3) correspondence of the remotely sensed albedo with in-situ observations from Greenland Climate Network (GC-Net) automatic weather stations (AWS) (Steffen et al., 1996); (4) correlation between changes in albedo with the NAO index; and (5) an overall negative albedo trend over the 1981-1998 period of study. Box et al. (2006) found a decline in ice sheet albedo for the 2000-2004 period using Moderate-resolution Imaging Spectroradiometer (MODIS) data processed using the Liang et al. (2005) algorithm.

The primary objectives of this study are to quantify and understand the spatial patterns of Greenland ice sheet albedo change, albedo sensitivity to near surface air temperature and precipitation, and the ice-albedo feedback. This is accomplished using satellite observations and regional climate model output both calibrated with in-situ observations. The surface energy budget is examined to identify key melt sensitivities. Analysis of regional atmospheric circulation anomalies permits attribution of the triggers and a cascade of causal mechanisms driving surface melting via albedo feedback and other physical processes.

\section{Data}

\subsection{In-situ observations}

GC-Net AWS (Steffen et al., 1996) provide hourly averages of $15 \mathrm{~s}$ measurements of surface upward and downward solar irradiance ( $S \downarrow$ and $S \uparrow$, respectively). The LI-COR $200 \mathrm{SZ}$ pyranometers are sensitive in the 0.4 to $1.1 \mu \mathrm{m}$ wavelength range. A +0.035 bias offset in $200 \mathrm{SZ}$ albedo was derived by Stroeve et al. (2006) in comparison with broadband $(0.3$ to $3.0 \mu \mathrm{m})$ pyranometers observations, owing to incomplete broadband sensitivity of the downward facing LI-COR pyranometer. $S \downarrow$ was found to be accurately measured. $T_{\text {air }}$ is sampled at $15 \mathrm{~s}$ intervals using thermocouples and at $60 \mathrm{~s}$ using Vaisala HMP45C thermistors shielded from direct solar irradiance (a.k.a. shortwave flux) by naturally aspirated white plastic enclosures. A $2-3 \mathrm{~K}$ root-mean-square (RMS) error correspondence is found between the hourly $T_{\text {air }}$ averages and instantaneous clear-sky MODIS surface temperature satellite-retrievals over Greenland (Hall et al., 2008a). Before computing monthly averages, the GC-Net $T_{\text {air }}$ data are quality controlled by rejecting hourly data for which there is a disagreement $>0.5 \mathrm{~K}$ between the thermocouples and the thermistors. At least $90 \%$ of possible cases must be available for monthly averages to be calculated and used in this study. Albedo computed from GC-Net $S \downarrow$ and $S \uparrow$ data is quality controlled on a monthly basis by rejecting albedo associated with monthly total $S \uparrow$ exceeding $S \downarrow$. Other cases of obvious pyranometer failure are rejected, for example due to heavy rime frost accretion when calculated monthly albedo values differ in the absolute by more than 0.2 from the satellite data.

\subsection{Satellite-derived albedo}

Surface albedo retrievals from the NASA Terra platform MODIS sensor MOD10A1 product beginning 5 March 2000 are available from the National Snow and Ice Data Center (NSIDC) (Hall et al., 2011). The daily MOD10A1 product is chosen instead of the MODIS MOD43 or MCD43 8-day products to increase temporal resolution. Release version 005 data are compiled over Greenland spanning March 2000 to October 2011. Surface albedo is calculated using the first seven visible and near-infrared MODIS bands (Klein and Stroeve, 2002; Klein and Barnett, 2003). The MOD10A1 product contains snow extent, snow albedo, fractional snow cover, and quality assessment data at $500 \mathrm{~m}$ resolution, gridded in a sinusoidal map projection. The data are interpolated to a $5 \mathrm{~km}$ Equal Area Scalable Earth (EASE) grid using the NSIDC regrid utility (http://nsidc.org/data/modis/ 
$\mathrm{ms} 2 \mathrm{gt} /$ ). The interpolation method employs a trend surface through the surrounding four $500 \mathrm{~m}$ grid cell values closest to the grid points. The resulting $5 \mathrm{~km}$ spatial resolution permits resolving the ablation area within the goals of this study. Major gaps in the time series occur 29 July-18 August 2000 and 14 June-7 July 2001. The frequency and quality of spaceborne albedo retrievals decrease in non-summer months as the amount of solar irradiance and solar incidence angles decrease. Also, in non-melting periods before April and after September, there are few valid data, especially in Northern Greenland because of the extremely low solar incidence angles. The accuracy of retrieving albedo from satellite or ground-based instruments declines as the solar zenith angle (SZA) increases, especially beyond $\sim 75^{\circ}$, resulting in many instances of albedo values that exceed the expected maximum clear sky snow albedo of 0.84 measured by Konzelmann and Ohmura (1995). Here, we limit problematic data by focusing on the June-August period when SZA is minimal.

Stroeve et al. (2006) concluded that the MOD10A1 data product captured the natural seasonal cycle in albedo, but exhibited significantly more temporal variability than recorded by ground observations. We now understand that a dominant component of this assessed error is the failure of the MODIS data product to completely remove cloud effects. Inspection of the raw MOD10A1 images reveals an abundance of residual cloud artifacts (shadows, contrails, thin clouds, cloud edges) in the albedo product, presumably because the similar spectral properties between snow and some clouds result in obvious cloud structures. Another problem consists of spuriously low values, for example below 0.4 in the accumulation area where albedo is not observed by pyranometers at the surface to drop below 0.7, seen as linear stripe artifacts in the imagery. Because both the cloud shadows and stripes introduce abrupt daily departures from the actual albedo time series, it is possible to reject them using a multi-day sample. Thus, on a pixel-by-pixel basis, 11-day running statistics are used to identify and reject values that exceed 2 standard deviations $(2 \sigma)$ from an 11-day average. To prevent rejecting potentially valid cases, data within 0.04 of the median are not rejected. The 11-day median is taken to represent each pixel in the daily data and has a smoothing effect on the albedo time series. June-August (JJA or summer) seasonal averages are generated from monthly averages of the daily filtered and smoothed data. Redundant data from the Aqua satellite MODIS instrument are not used in this study for simplicity, to reduce computational burdens, and given an Aqua MODIS instrument near infrared (channel 6) failure (Hall et al., 2008a) that reduces the cloud detection capability.

\subsection{Land surface temperature}

MODIS thermal infrared observations enable retrieval of land surface temperature $\left(T_{\text {surface }}\right)$ under cloud-free conditions at $1 \mathrm{~km}$ horizontal resolution. The MODIS MOD11A1 data product is based on daily averaged $T_{\text {surface }}$ retrievals from swath data and a split-window algorithm using MODIS bands $31(11 \mu \mathrm{m})$ and $32(12 \mu \mathrm{m})$ (Wan et al., 2002). These data have a RMS error $\leq 1{ }^{\circ} \mathrm{C}$ in comparison with independent in-situ observations (Wan et al., 2008), with higher RMS errors (find RMS error $\leq 1^{\circ} \mathrm{C}$ ) found over Greenland (Hall et al., 2008a; Hall et al., 2008b).

\subsection{MODIS MOD10A1 validation}

We compare MOD10A1 albedo with GC-Net albedo for the 2000-2010 time period at 17 GC-Net sites within the 550$3250 \mathrm{~m}$ elevation range. Comparisons are made with the nearest MODIS $5 \mathrm{~km}$ grid cell that essentially includes the GC-Net position within the grid cell area. Months with less than $90 \%$ possible of the hourly samples data are not considered. Under high SZA, GC-Net LI-COR 200-SZ pyranometer errors become extreme, especially for the downward facing sensor. This error is minimized by using monthly totals of paired hourly $S \downarrow$ and $S \uparrow$ data in the albedo calculation:

$\alpha=\sum S \uparrow / \sum S \downarrow$

While cases when SZA is high are included in this calculation, their contribution to the total is negligible (van den Broeke et al., 2004). Other error sources than station tilt include, for example, bias when a thin snow cover is present on the upward sensor surface and $S \downarrow$ is still greater than $S \uparrow$ and are not compensated here.

GC-Net albedos are measured under all-sky conditions, while MODIS MOD10A1 data are retrieved exclusively for clear-sky conditions. All-sky GC-Net albedo data will thus include the effect of clouds, increasing calculated albedo because of cloudy cases. Consulting Fig. 1 in which no significant bias is found between the all-sky GC-Net data and the MOD10A1 data, the effect of cloudiness on GC-Net data seems within the residual uncertainty between these independent data sets. Otherwise, there may be some offset in the absolute accuracy of the MOD10A1 data. Yet, that offset was not apparent in the Stroeve et al. (2006) comparisons in which the GC-Net data were selected using a cloud clearing methodology Box (1997). In either case, the absolute bias is less than the RMSE and here is not compensated further.

Averaging MODIS data within $10 \mathrm{~km}$ of the GC-Net AWS location yields RMSE values of $0.041 \pm 0.011$ (Fig. 1). This RMSE finding is smaller by nearly a factor of two than found by Stroeve et al. (2006), because monthly instead of daily means are considered and the cloud artifact and image stripe outlier rejection described in the previous section greatly reduce spurious temporal variability. While the residual bias $(-0.006 \pm 0.008)$ is indistinguishable from zero, there is evidence of positive skew in the MODIS data above 0.84 when pyranometers report albedo exceeding 0.84 only under cloudy skies (Konzelmann and Ohmura, 1995). Ground measurements of albedo greater than 0.84 under cloudy conditions are attributable to the relative increase in the absorption 

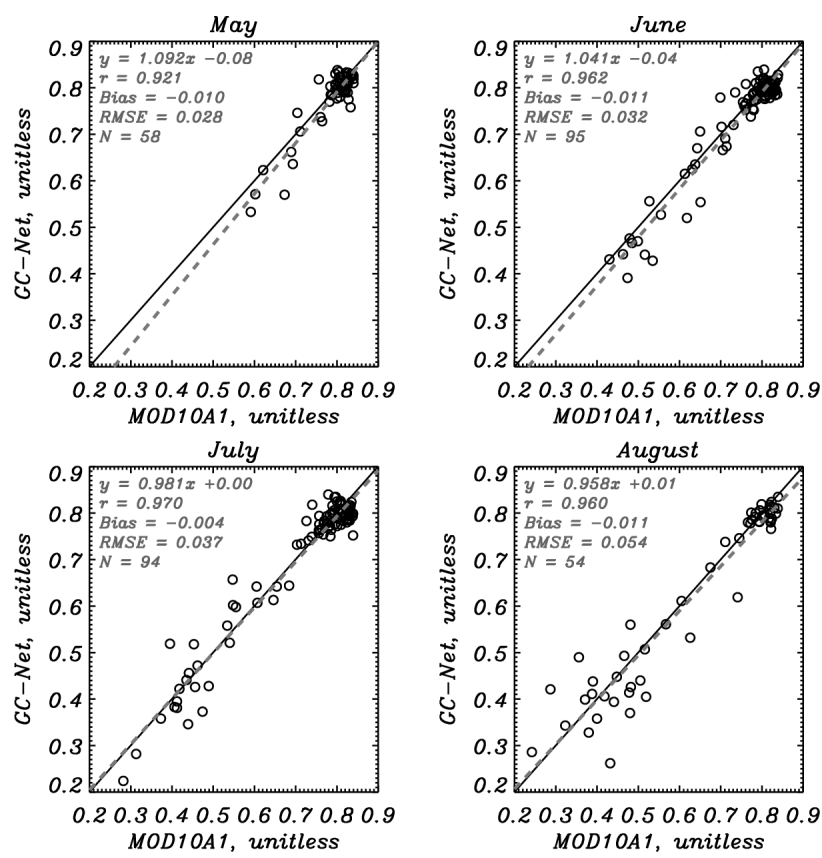

Fig. 1. Comparison of the monthly averaged MODIS MOD10A1 values less than 0.84 within $10 \mathrm{~km}$ of $17 \mathrm{GC}-\mathrm{Net}$ automatic weather stations. The June-August average RMS error is 0.041 .

of the downward near-infrared solar irradiance by clouds. The MODIS albedo algorithm does not provide a surface albedo estimate under cloudy skies. In addition, extremely high ( $>0.9)$ MOD10A1 values are found at high $(>\sim 1500$ $\mathrm{m}$ ) elevations in the most northerly latitudes where SZA is high, and when the uncertainty in the MOD10A1 albedo is also high as noted by the accompanying data quality flag. It is nonetheless possible to conclude that the MOD10A1 product is accurate in representing Greenland ice sheet albedo in the range from 0.26 to 0.84 , in which we have nearly simultaneous and coincident GC-Net AWS observations. Comparisons are not made when MODIS albedos exceed 0.84 .

Minimum ice sheet albedo values in the MOD10A1 product over the part of Greenland that our land mask classifies the surface as permanent ice are 0.31 . It is important to be explicit about the use of a mask, because some lower albedo debris-covered area may be excluded. The lowest reported GC-Net albedo measurement (0.259) is from the JAR1 site for July 2010. The JAR1 AWS is situated in the most impurity rich parts of the ablation area (Wientjes and Oerlemans, 2010) where values of 0.31 are estimated by Knap and Oerlemans (1996).

\subsection{The MAR regional climate model}

A source of climate parameters distributed over all of the Greenland ice sheet is needed in this study to evaluate albedo sensitivity to $T_{\text {air }}$ and albedo feedback with $T_{\text {air }}$ and $S \downarrow$. The observationally constrained Modèle Atmosphèrique
Régional (MAR) (Fettweis et al., 2011a) is coupled with a one-dimensional multi-layered energy balance snow model (Gallée and Schayes, 1994; Lefebre et al., 2003). The temperature, albedo, precipitation and surface melt simulated by MAR have been validated (Lefebre et al., 2003, 2005; Fettweis et al., 2005, 2011a,b). The ability of MAR to realistically simulate the surface mass balance over the ice sheet has been established (Fettweis, 2007; Tedesco et al., 2011). The MAR version used here is calibrated to best compare with the satellite passive microwave-derived melt extent from 1979-2009 (Fettweis et al., 2011a). A tundra/ice mask is used based on the Greenland land surface classification mask from a MODIS classification (http://bprc.osu.edu/wiki/ Jason_Box_Datasets), and the model terrain (Bamber et al., 2001) is smoothed (Fettweis et al., 2005). MAR is run with a horizontal resolution of $25 \mathrm{~km}$ and is forced each $6 \mathrm{~h}$ at the lateral boundaries by the European Centre for Medium Range Weather Forecasts (ECMWF) ERA-INTERIM reanalysis (Dee et al., 2011). MAR data are attractive for use here, because they are available at higher spatial resolution than global re-analyses, sufficient to resolve spatial gradients (Franco et al., 2012) in $T_{\text {air }}, S \downarrow$, snow and rainfall, and several other parameters mentioned later. Here, the MAR data are resampled and reprojected to the $5 \mathrm{~km}$ MODIS albedo data grid (EASE-Grid), described earlier.

\subsection{MAR validation}

GC-Net data are used to evaluate the accuracy of MAR sim-

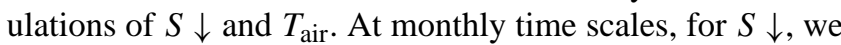
find that the MAR RMS error is equivalent to the GC-Net sensor uncertainty of $15 \mathrm{~W} \mathrm{~m}^{-2}$, equal to the $5 \%$ instrument specifications under $300 \mathrm{~W} \mathrm{~m}^{-2}$ irradiance. The average biases are less than the specified GC-Net sensor error. However, a systematic bias is evident for June, July, and August, with regression slopes between 0.81 and 0.84 , suggesting that MAR has 16-19\% too much shortwave cloud opacity in the lower half of the distribution. To meet the goal of assessing the albedo feedback with maximum accuracy, the regression functions illustrated in Fig. 2 are used to calibrate MAR $S \downarrow$. Assuming all absolute and systematic error is attributed to MAR and that these errors are temporally homogeneous, the monthly regression functions are applied to the monthly average MAR data prior to calculating seasonal averages. Only JJA data are used in this study to evaluate the albedo sensitivity to temperature and albedo feedback.

Monthly averages from GC-Net for the 2000-2010 period are used to evaluate the accuracy of monthly average MAR simulations of $T_{\text {air }}$ illustrated in Fig. 3. The average bias grows from $0{ }^{\circ} \mathrm{C}$ in June with an RMS error of $1.1^{\circ} \mathrm{C}$ to a minor positive bias in July and an obvious systematic bias in August. The MAR cold bias in July/August is a consequence of an underestimation of $L \downarrow$ (Fettweis et al., 2011a). However, it should be noted that this bias occurs for pixels with temperatures below $-10^{\circ} \mathrm{C}$ where little melting is 

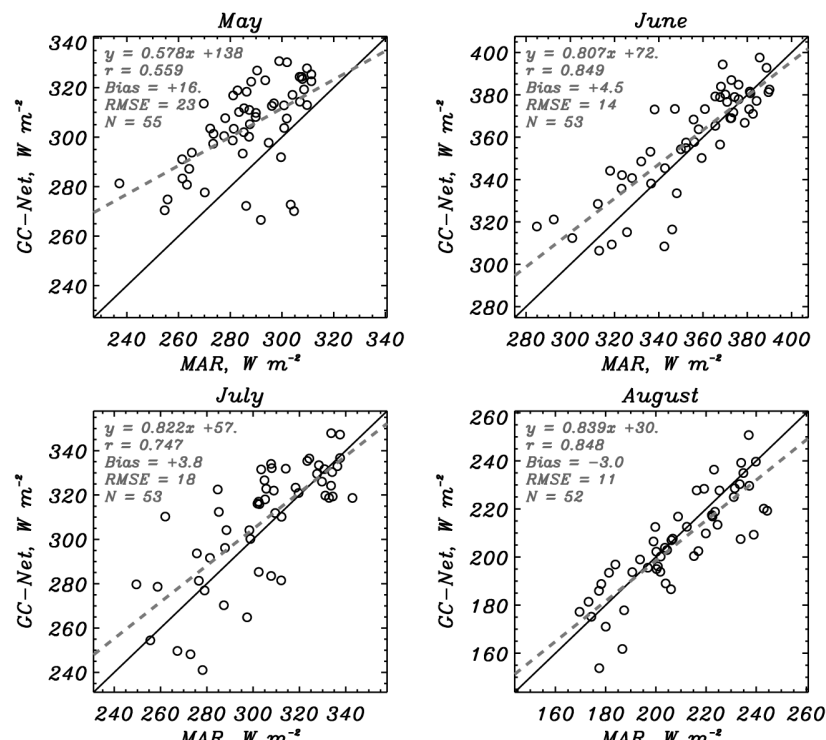

Fig. 2. Comparison of monthly averaged MAR simulations of downward shortwave irradiance with observations from GC-Net automatic weather stations spanning the 2000-2010 period when GCNet $S \downarrow$ data are available for this study.

simulated. As with $S \downarrow$, to minimize bias, the MAR $T_{\text {air }}$ data are calibrated using the monthly regression functions. The post-calibration RMS error is $1.0^{\circ} \mathrm{C}$.

Additional MAR variables used in this study include the turbulent heat fluxes: $Q_{\mathrm{SH}}$ and $Q_{\mathrm{LH}}$. Energy fluxes that heat the surface are positive in this budget. The net turbulent flux $\left(Q_{\mathrm{SH}}+Q_{\mathrm{LH}}\right)$ is also referred to in this study. Downward longwave irradiance $(L \downarrow)$ is used to evaluate changes in allsky downward thermal emission. Similarly, the total downward irradiance, the sum of $S \downarrow+L \downarrow$ (hereafter $R \downarrow$ ), is useful to evaluate total surface incident radiation flux density.

\subsection{Surface mass balance}

Grey tones in Fig. 4 indicate the mean ablation area over the 2000-2011 period, according to MAR, where the calculated annual melt and runoff exceed the snow accumulation rate and the surface mass balance (SMB) is negative. Colored regions indicate the accumulation area according to MAR where SMB is positive. The equilibrium line separates the $\sim 1.428 \pm 0.131 \times 10^{6} \mathrm{~km}^{2}$ net snow accumulation area from the $0.414 \pm 0.249 \times 10^{6} \mathrm{~km}^{2}$ net ice ablation area. The $\mathrm{km}^{2}$ areas are from the MAR simulations in the 2000-2011 period. The values following " \pm " indicate $1 \sigma$ of 11 hydrologic year samples ending in 2011.

\subsection{Surface melt extent}

Greenland melt extent is mapped using passive microwave observations from the NOAA/NASA Pathfinder SSM/I Level 3 EASE-Grid Brightness Temperature data recorded by
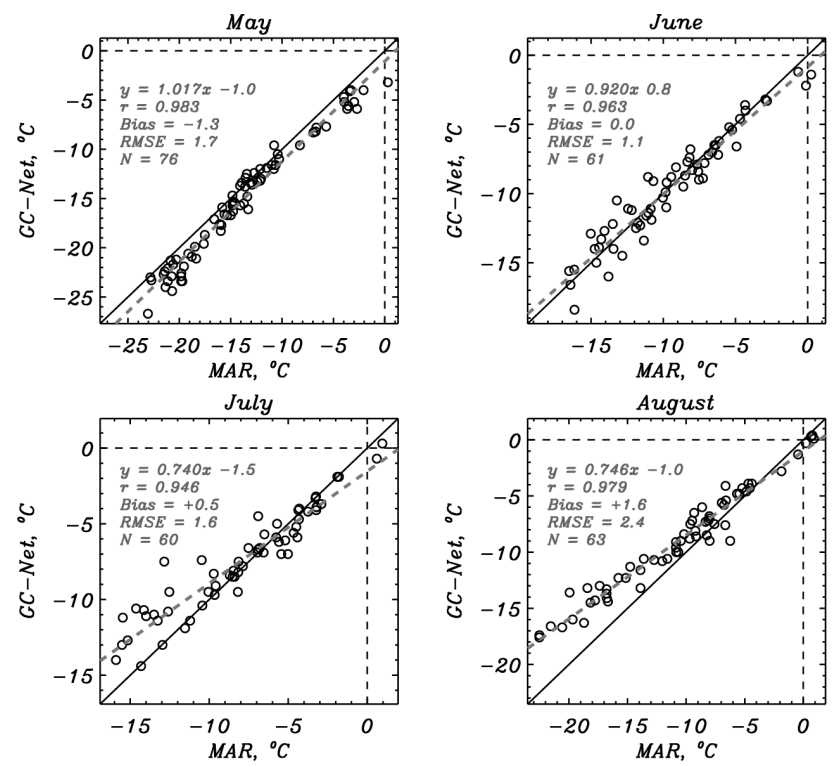

Fig. 3. Comparison of monthly averaged MAR simulations of surface air temperature with observations from GC-Net automatic weather stations for the 2000-2010 when GC-Net $T_{\text {air }}$ data are available for this study.
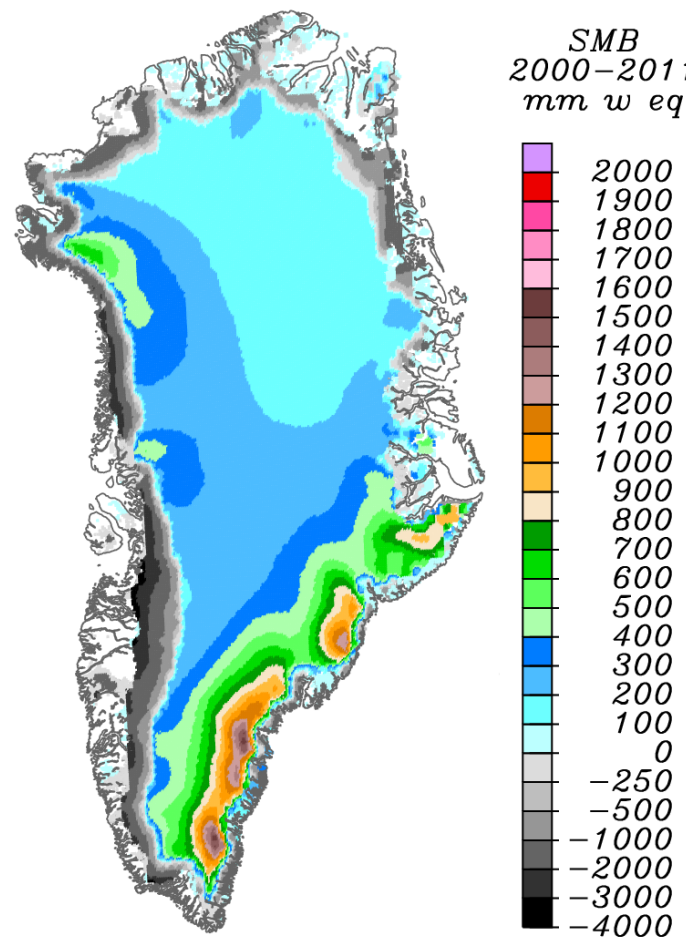

Fig. 4. Surface mass balance averaged spanning the $12 \mathrm{yr}$ of this study (2000-2011) according to MAR simulations. Grey tones indicate the ablation area. Colored regions indicate the accumulation area. 
the Special Sensor Microwave/Imager (SSM/I) flown on the satellites of the Defense Meteorological Satellite Program (DMSP, F08, F11, F13 and F17). The data are gridded to a $25 \mathrm{~km}$ resolution (http://nsidc.org/data/docs/daac/ nsidc0032_ssmi_ease_tbs.gd.html) and are available from NSIDC (http://nsidc.org/data/nsidc-0032.html). When snow melts, the imaginary part of snow permittivity increases as a consequence of the presence of liquid water, causing an increase in the absorption and, therefore, microwave brightness temperature (Chang et al., 1976; Mote and Anderson, 1995; Abdalati and Steffen, 2001; Mote, 2007; Tedesco, 2007; Fettweis et al., 2011a). Conversely, brightness temperatures over dry snow are relatively low and this is especially true in Greenland where ice (not land) lies below the snowpack. Brightness temperatures can also increase because of a decrease in effective grain size due to new snow or changes in snow temperature. However, these processes are much slower than those associated with the appearance of liquid water within the snowpack within a diurnal cycle. Melting is here detected when the difference between ascending and descending brightness temperatures (DAV) measured at $19.35 \mathrm{GHz}$, or when the absolute value of either ascending or descending brightness temperatures exceeds the estimated threshold values (Tedesco, 2007).

\section{Methods}

The physical processes driving surface melt over ice are isolated using a surface energy budget:

$$
Q_{\mathrm{SH}}+Q_{\mathrm{LH}}+Q_{\mathrm{G}}=R_{\mathrm{N}}=L_{\text {net }}+S_{\text {net }}
$$

where $Q_{\mathrm{SH}}$ and $Q_{\mathrm{LH}}$ are the turbulent sensible and latent heat fluxes, respectively. Persistent temperature inversions over ice sheets lead $Q_{\mathrm{SH}}$ to be a surface energy source most of the year (van den Broeke et al., 2008). $Q_{\mathrm{LH}}$ is an energy sink where evaporation or sublimation absorbs latent heat. $Q_{\mathrm{LH}}$ can be a melt energy source in the lower ablation area (van den Broeke et al., 2008). $Q_{\mathrm{G}}$ is the subsurface conductive sensible heat flux. $R_{\mathrm{N}}$ is the net vertical radiation energy flux that tends toward balance over time with the non-radiative fluxes. $L_{\text {net }}$ is the difference between downward and upward infrared irradiance $(L \downarrow-L \uparrow)$. $S_{\text {net }}$ represents surface absorbed solar energy. $S_{\text {net }}$ depends on $S \downarrow$ and the surface albedo $(\alpha)$, defined as the ratio of the upward to downward solar irradiance in the $0.3 \mu \mathrm{m}$ to $4 \mu \mathrm{m}$ spectrum:

$S_{\text {net }}=S \downarrow(1-\alpha)$.

$S \downarrow$ peaks in summer months and is modulated by cloud optical thickness and solar illumination geometry. The latter depends significantly on the $23^{\circ}$ latitudinal extent of the ice sheet. Units of energy fluxes are $\mathrm{W} \mathrm{m}^{-2}$.

Melt water volume $(M)$, expressed in units of $\mathrm{mm}$ water equivalence ( $\mathrm{mm}$ w.e.), is calculated by MAR from surface energy budget closure:
$M=\left(R_{\mathrm{N}}-\left(Q_{\mathrm{SH}}+Q_{\mathrm{LH}}+Q_{\mathrm{G}}\right)\right) \Delta t\left(L_{\mathrm{f}} \rho\right)^{-1}$

where $\Delta t$ is the time interval (s); $L_{\mathrm{f}}$ is the latent heat of fusion $\left(3.335 \times 10^{5} \mathrm{~J} \mathrm{~kg}^{-1}\right)$; and $\rho$ is the density of water $\left(1000 \mathrm{~kg} \mathrm{~m}^{-3}\right)$. The associated melt extent has been validated (Tedesco et al., 2011) with SMB observations from the K-transect along the western ice sheet and with satellite microwave observations (Fettweis et al., 2011a). The interannual variability and magnitude of MAR-derived $M$, driven by the ERA-Interim reanalysis, correspond closely with the in situ and satellite-derived observations. As for the unvalidated parameters $Q_{\mathrm{SH}}$ and $Q_{\mathrm{LH}}$, it is the relative and interannual magnitude of variability rather than the absolute magnitude that is of primary interest. As such, absolute error is minimized. MAR-simulated $Q_{\mathrm{G}}$ for June-August is calculated to be the smallest surface energy budget term, approaching zero in the upper $1 \mathrm{~m}$ of the ablation area and is only analyzed indirectly in this study via its contribution to $M$.

In the interest of understanding possible changes in the importance of net shortwave flux ( $S_{\text {net }}$ ) to $M$, surface melt duration $\left(\Delta t_{\text {melting }}\right)$ defined using passive microwave (Tedesco, 2007 ) is used to define melting attributable to net shortwave flux alone:

$M_{\text {net shortwave flux }}=S_{\text {net }} \Delta t_{\text {melting }}\left(L_{\mathrm{f}} \rho\right)^{-1}$.

While partitioning in this way is somewhat arbitrary since it is the net surface energy that governs $M$, and $S_{\text {net }}$ may be greater than net surface energy for periods shorter than three months, the temporal change in the ratio $M_{\text {net shortwave flux }} / M$ yields an estimate of the relative importance of net shortwave flux to melting. Over time, this ratio indirectly yields the changing importance the albedo feedback to $M$.

The albedo sensitivity to near-surface air temperature (at $\sim 3 \mathrm{~m}$ above the surface in MAR calculations), expressed here in units of $\%$ albedo $\mathrm{K}^{-1}$ using the $\alpha^{*}$ symbol, is determined by regression between 12 annual samples of detrended anomalies of June-August average $\alpha$ and $T_{\text {air }}$. It is worth emphasizing that the regression is not between successive values in time series but is made using annual pairs of anomalies. This pairing is illustrated in Fig. 5. In the same manner, we quantify the albedo feedback in units of $\mathrm{W} \mathrm{m}^{-2} \mathrm{~K}^{-1}$ using annual pairs of summer average anomalies in $\alpha, S_{\text {net }}$ and $T_{\text {air }}$, anomalies indicated by the ${ }^{\prime}$ character in $\Delta^{\prime}$ :

$\alpha_{\text {feedback, a }}=\Delta^{\prime} S \downarrow\left(1-\Delta^{\prime} \alpha\right) / \Delta^{\prime} T_{\text {air }}=\Delta^{\prime} S_{\text {net }} / \Delta^{\prime} T_{\text {air }}$.

This definition of albedo feedback does not include lags, which may contribute to albedo change. Indeed, there is some evidence discussed relative to Fig. 6 whereby residual low year 2010 albedo may have pre-conditioned year 2011 for low albedo. Therefore, an alternative formulation for albedo feedback (here referred to as the bulk 

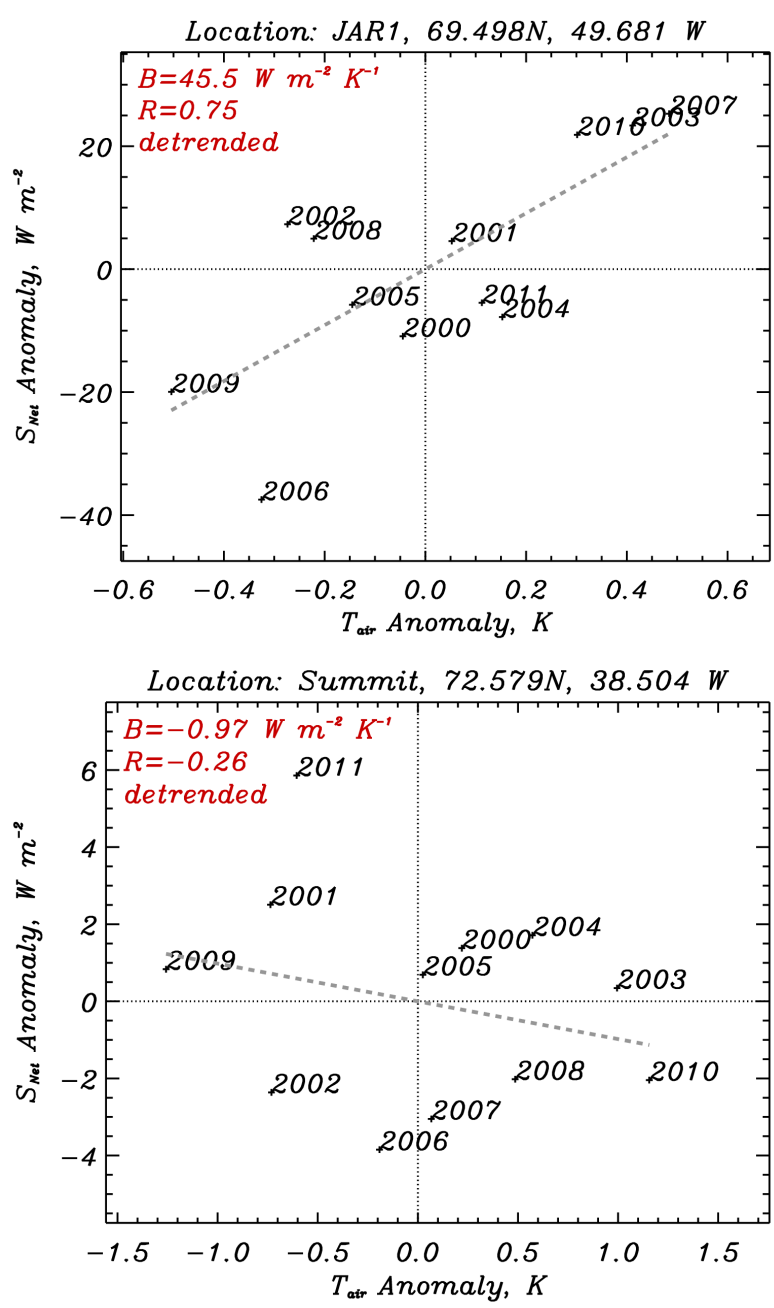

Fig. 5. Examples of albedo feedback calculated by regression of inter annual anomalies. The $5 \mathrm{~km}$ grid cell locations illustrated here are coincident with GC-Net AWS sites, but more importantly illustrate the differences between the ablation and accumulation areas. The dashed grey line indicates the regression slope that is here used to quantify the sign and magnitude of the albedo feedback.

feedback $\left.\left(\alpha_{\text {feedback,b }}\right)\right)$ is the change in net shortwave flux, $\Delta S_{\text {net }} / \Delta T_{\text {air }}$, over time. While $\alpha_{\text {feedback,b }}$ may more explicitly represent the energy system to the first order, computing feedback from pairing of anomalies (Fig. 5) yields a insight into the importance of, for example, snowfall in a secondorder role of modulating albedo sensitivity to $T_{\text {air }}$. The value of $\alpha_{\text {feedback,a }}$ becomes increasingly clear throughout the remainder of this paper.

Freshly fallen snow under clear skies has an albedo of $\sim 0.84$ (Konzelmann and Ohmura, 1995), progressively reducing during the sunlit (warm) season as a consequence of ice grain growth, resulting in a self-amplifying albedo decrease. The complete melting of the winter snow accumulation on ice sheets at the low elevations exposes underlying glacier ice in the ablation area. In this region, the albedo of

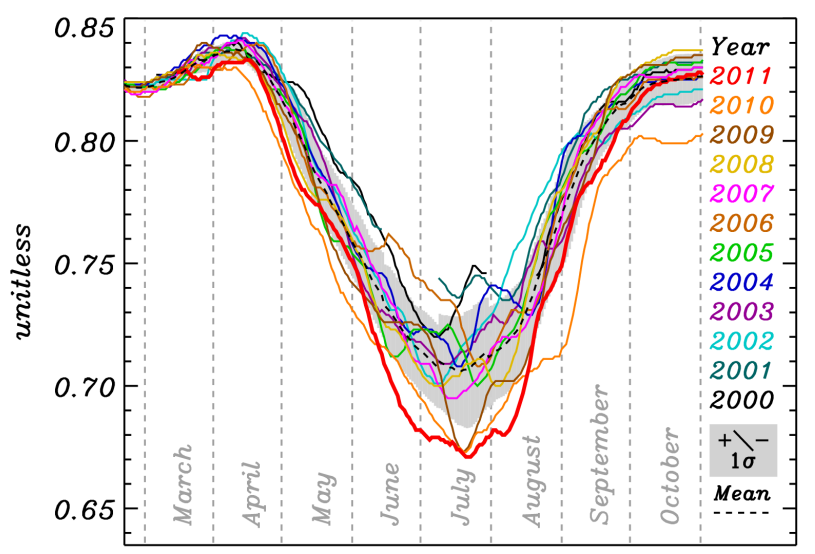

Fig. 6. 11-day running median Greenland ice sheet albedo from Moderate Resolution Imaging Spectroradiometer (MODIS) MOD10A1 data.

low-impurity snow-free glacier ice is in the range of 0.30 to 0.60 (Cuffey and Paterson, 2010, Table 5.2). Where aeolian and microbiological impurities accumulate near the glacier ice surface (Bøggild et al., 2010), the albedo may be extremely low (0.20). Thus, intraseasonal summer albedo variability exceeds 0.50 over parts of the ice sheet where a snow layer ablates by mid-summer, exposing an impurity-rich ice surface (Knap and Oerlemans, 1996; Wientjes and Oerlemans, 2010), resulting in $S_{\text {net }}$ being the largest source of energy for melting during summer and explaining most of the inter-annual variability in melt totals (van den Broeke et al., 2011). The accumulation area is also susceptible to albedo feedback from grain growth metamorphism occurring in subfreezing conditions.

Temporal changes in any of the variables are considered "significant" if the 12-yr regression slope multiplied by the number of years, i.e. the "change", exceeds $1 \sigma$ of the residuals of the linear fit. The $1 \sigma$ uncertainty envelope is presented immediately after slope values using the \pm symbol.

\section{Results}

\subsection{Albedo seasonal and inter-annual variability}

The average albedo of the ice sheet declines from 0.835 in April to 0.707 by mid-July (Fig. 6). Meltwater production and extent according to spaceborne passive microwave remote sensing generally peak in July (Mote, 2007), when $T_{\text {air }}$ reaches its annual maximum. As the melt season ends, snow accumulation brightens the surface. Yet, because of extreme 2010 melt and little snow accumulation during the melt season (Tedesco et al., 2011) and afterward, the ice sheet albedo remained more than $2 \sigma$ below the 2000-2011 average much of September and October. However, albedo measurements over Greenland after August have increasingly low accuracy confidence since the solar zenith angle increases high during 
the non-melt season months at these latitudes. Still, in the following year, June and July 2011 ice sheet albedo reached its lowest observed values despite temperatures being on average lower than in 2010, suggesting a progressive multi-year albedo decline from albedo feedback.

According to linear regression, the ablation area albedo declined from 0.715 in 2000 to 0.632 in 2011 (time correlation $=-0.805,1-p=0.999)$. The change $(-0.083)$ is more than two times the absolute albedo RMS error $( \pm 0.041)$. Over the accumulation area, the highly linear (time correlation $=-0.927,1-p>0.999$ ) decline from 0.817 to 0.766 (change: -0.051 ) over the same period is larger than $2 \sigma$ of the regression residuals and also exceeds the absolute albedo RMS error.

\subsection{Albedo trend verification}

Degrading MODIS instrument sensitivity identified by Wang et al. (2012) introduces the possibility that the declining albedo trends may be erroneous. To validate the MODIS albedo trends, coinciding observations from GC-Net AWS are examined. The ground truth data are situated across a range of elevations, spanning the ablation and accumulation areas.

Analysis of the GC-Net data confirms declining albedo trends in the 2000-2010 period to be widespread in individual months from May-September. Trend statistics are computed where at least $7 \mathrm{yr}$ of annual data are available from both GC-Net and MODIS Terra. Significance is designated here more strictly where the trend measured by the linear regression slope has a magnitude that exceeds $2 \sigma$ of the residuals from the regression. In 41 of $43(95 \%)$ of monthly cases May-September, the trend is found to be significant and decreasing (Table 1). In 10 of $14(71 \%)$ cases, for which both GC-Net and MOD10A1 trends are significant, the GC-Net declining trend is larger than the MOD10A1 trend. It therefore does not seem that MODIS sensor degradation is enhancing an existing trend.

It seems improbable that degradation of the GC-Net photoelectric diode pyranometers produces an erroneous declining albedo trend. If both upward and downward facing sensors degrade at the same rate, the albedo would not change in time due to progressive sensor bias. An erroneous declining trend would require that the downward facing pyranometer degrades faster than the upward facing pyranometer. If the degradation is increased by exposure to sunlight as it is with optical black lacquer pyranometers, then the upward pyranometer would be expected to degrade faster, introducing an erroneous increasing albedo trend. We observe the opposite.

The largest magnitude declining albedo trends are evident at the sites located in the ablation zone such as JAR1 and Swiss Camp. In the more southerly yet relatively high elevation sites of Saddle and South Dome where melting is uncommon in passive microwave observations (e.g. Mote,
2007; Tedesco, 2007), declining albedo trends are observed consistently in individual months (Table 1).

The time series at the Summit AWS is valuable to validate the MOD10A1 trend for regions of the ice sheet where surface melting is not observed by passive microwave remote sensing and, if occurring in contemporary climate, remains rare. At Summit, the declining albedo trend magnitudes among GC-Net and MOD10A1 results for individual months May-July are consistently negative (Table 1).

Coherent interannual variability is evident in the correlation between synchronous GC-Net and MOD10A1 data, as characterized by correlation coefficients above 0.7 in 16 of 25 (or $64 \%$ ) cases (Table 1), suggesting that both independent observations capture the same interannual variability. For example, in June at JAR1 in the ablation area, the correlation is 0.938. At Saddle where there is little to no evidence of surface melting in June, the correlation is 0.919 .

\subsection{Regional albedo trends}

Regionally, the albedo decline in recent years is greatest in the ablation area (Fig. 7a). Large-scale albedo decline is evident where relatively gradual surface slopes permit wide ablation areas, namely the southwest, northwest and northeast regions. A decreasing duration of snow cover over low albedo glacier ice and an expansion of the bare ice area are observed especially over the southwestern ice sheet ablation area (Tedesco et al., 2011; van As et al., 2011). For $58 \%$ of the ice sheet area, the 12-yr albedo change exceeds the absolute albedo RMS error of 0.041 . Over $87 \%$ of the area, the change exceeds $2 \sigma$ of the regression residuals. Averaged over the accumulation area, the albedo decrease $(-0.051)$ exceeds the absolute uncertainty. The residuals to the linear fit for the accumulation area are small $(1 \sigma=0.006)$, indicating a highly linear declining trend. In the $6.2 \times 10^{5} \mathrm{~km}^{2}$ area above $2500 \mathrm{~m}$ where surface melting has not been detected by passive microwave melt retrievals, an albedo decrease $(-0.040)$ is also evident, from 0.842 in year 2000 to 0.803 in 2011 (time correlation $=-0.915,1-p>0.999$ ), suggesting that the albedo decline is not only driven by active melting but by enhanced grain metamorphism.

The 2000-2011 $S \downarrow$ change is marked by an increase over the northwestern ice sheet and to a lesser extent over the southwestern ice sheet (Fig. 7b). A decreasing $S \downarrow$ trend is evident over the eastern ice sheet.

The 12-yr change in June-August (JJA) $S \downarrow$ and albedo (Fig. 7a,b) is associated with an increase in solar absorption over the ablation area by $45 \times 10^{18} \mathrm{~J}$ (or 45 exajoules). Using passive microwave melt days to partition this energy using melt duration, the linear regression change indicates an additional $24 \mathrm{EJ}$ is sunk into melting in 2011 compared with 2000 , equivalent with a $72 \mathrm{Gt}$ increase in melt water production over the period. According to total energy budget closure simulated by MAR, increased absorbed solar radiation accounts for $85 \%$ of this melt increase from $331 \mathrm{Gt}$ in 2000 
Table 1. Comparison of albedo trends in MODIS MOD10A1 and GC-Net observations for statistically significant cases.

\begin{tabular}{|c|c|c|c|c|c|}
\hline Month & GC-Net Site & $\begin{array}{l}\text { Albedo Data } \\
\text { Source }\end{array}$ & $\begin{array}{r}\text { Albedo Trend, } \\
\text { decade }^{-1}\end{array}$ & $\begin{array}{r}\text { Nbr } \\
\text { Years }\end{array}$ & $\begin{array}{r}\text { GC-Net vs. MODIS } \\
\text { correlation }\end{array}$ \\
\hline \multirow[t]{10}{*}{ May } & Summit & GC-NET & -0.026 & 11 & 0.649 \\
\hline & Summit & MOD10A1 & -0.028 & 11 & \\
\hline & Tunu-N & MOD10A1 & -0.033 & 11 & \\
\hline & DYE-2 & GC-NET & -0.034 & 9 & 0.888 \\
\hline & DYE-2 & MOD10A1 & -0.030 & 9 & \\
\hline & Saddle & GC-NET & -0.040 & 11 & 0.733 \\
\hline & Saddle & MOD10A1 & -0.030 & 11 & \\
\hline & NASA-E & MOD10A1 & -0.035 & 9 & \\
\hline & NASA-SE & MOD10A1 & -0.027 & 8 & \\
\hline & JAR2 & GC-NET & -0.188 & 8 & 0.826 \\
\hline \multirow[t]{10}{*}{ Jun } & $\mathrm{CP} 1$ & GC-NET & +0.076 & 7 & -0.036 \\
\hline & Summit & GC-NET & -0.026 & 10 & 0.768 \\
\hline & Summit & MOD10A1 & -0.023 & 10 & \\
\hline & Tunu-N & GC-NET & +0.022 & 8 & -0.452 \\
\hline & DYE-2 & GC-NET & -0.044 & 8 & 0.820 \\
\hline & DYE-2 & MOD10A1 & -0.040 & 8 & \\
\hline & JAR1 & GC-NET & -0.268 & 9 & 0.938 \\
\hline & Saddle & GC-NET & -0.048 & 8 & 0.919 \\
\hline & Saddle & MOD10A1 & -0.032 & 8 & \\
\hline & JAR2 & GC-NET & -0.089 & 9 & 0.783 \\
\hline \multirow[t]{14}{*}{ Jul } & Swiss Camp & GC-NET & -0.134 & 8 & 0.907 \\
\hline & Swiss Camp & MOD10A1 & -0.161 & 8 & \\
\hline & $\mathrm{CP} 1$ & MOD10A1 & -0.049 & 8 & \\
\hline & Summit & GC-NET & -0.031 & 10 & 0.695 \\
\hline & Summit & MOD10A1 & -0.031 & 10 & \\
\hline & DYE-2 & GC-NET & -0.054 & 7 & 0.790 \\
\hline & JAR1 & GC-NET & -0.343 & 10 & 0.948 \\
\hline & Saddle & GC-NET & -0.066 & 9 & 0.876 \\
\hline & Saddle & MOD10A1 & -0.050 & 9 & \\
\hline & South Dome & GC-NET & -0.075 & 7 & 0.772 \\
\hline & South Dome & MOD10A1 & -0.041 & 7 & \\
\hline & NASA-SE & GC-NET & -0.071 & 7 & 0.787 \\
\hline & NASA-SE & MOD10A1 & -0.051 & 7 & \\
\hline & JAR2 & MOD10A1 & -0.070 & 9 & \\
\hline \multirow[t]{6}{*}{ Aug } & Swiss Camp & GC-NET & -0.198 & 7 & 0.869 \\
\hline & Swiss Camp & MOD10A1 & -0.293 & 7 & \\
\hline & DYE-2 & GC-NET & -0.053 & 7 & 0.843 \\
\hline & JAR1 & GC-NET & -0.239 & 11 & 0.693 \\
\hline & JAR1 & MOD10A1 & -0.288 & 11 & \\
\hline & JAR2 & MOD10A1 & -0.097 & 9 & \\
\hline \multirow[t]{3}{*}{ Sep } & Summit & GC-NET & -0.055 & 8 & 0.220 \\
\hline & JAR1 & GC-NET & -0.369 & 9 & 0.491 \\
\hline & JAR2 & GC-NET & -0.133 & 9 & 0.622 \\
\hline
\end{tabular}

to $416 \mathrm{Gt}$ in 2011. Also according to MAR, June-August is when $93 \%$ of the total annual melting occurs. From this, it is possible to conclude that positive feedback prevailing over the ablation area accounts for $81 \%$ of the increase in melt rates. Before examining the albedo feedback amplification of melt further, implications of the radiation budget changes and causal factors are presented.
In the accumulation area, despite higher overall albedo than the ablation area, the 4.3 times larger area and higher $S \downarrow$ resulted in it absorbing three times more solar energy. Yet, because accumulation area melting is $\sim 8$ times less in time duration according to passive microwave, most of this additional absorbed solar energy is used not in melting but in snowpack heating. In an example with realistic boundary conditions, the additional $148 \mathrm{EJ}$ solar energy is sufficient to 

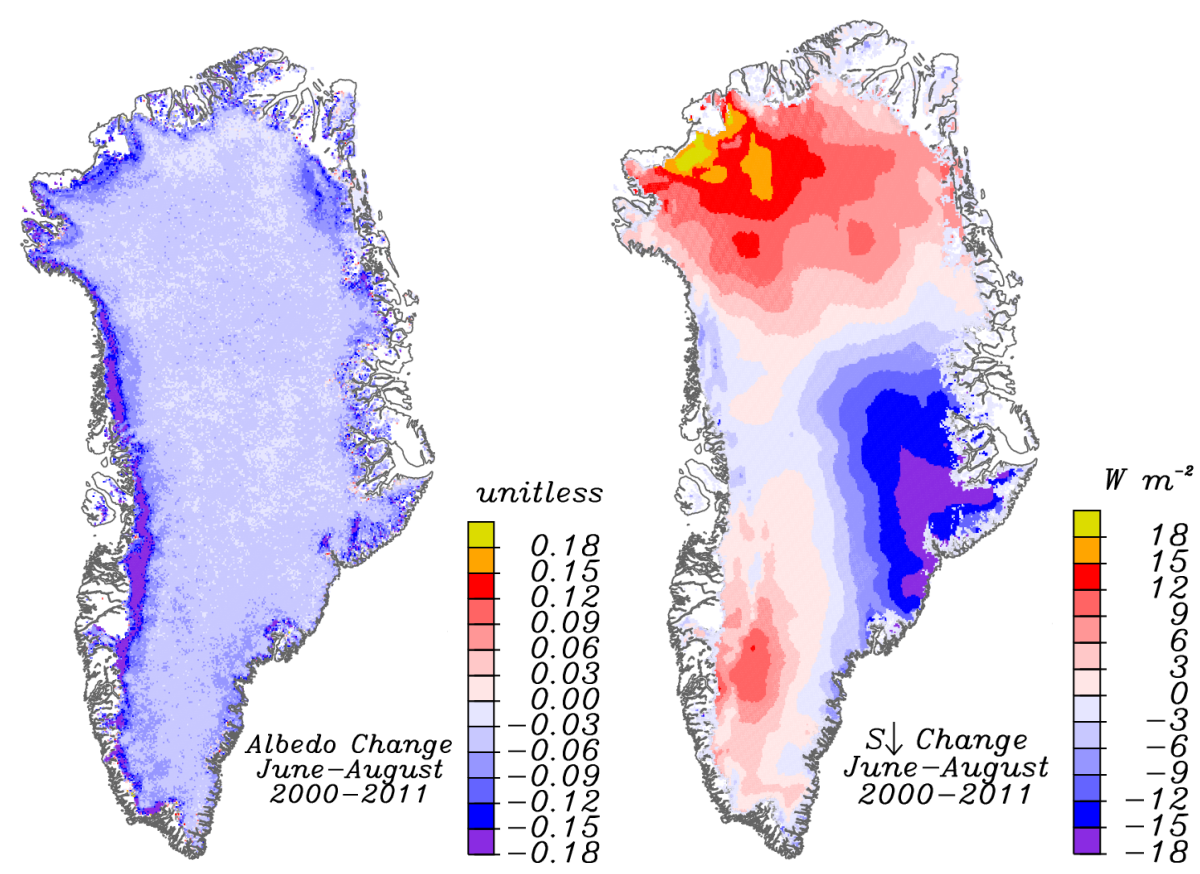

Fig. 7. (a) Summer (June-August) spatial patterns MODIS MOD10A1 $5 \mathrm{~km}$ albedo temporal change 2000-2011 derived from the linear regression. (b) Summer change in MAR downward shortwave simulations calibrated using GC-Net AWS data.

completely erode the "cold content" of the $1.494 \times 10^{6} \mathrm{~km}^{2}$ accumulation area to a depth of $14 \mathrm{~cm}$, assuming its temperature, density, and specific heat to be $-10^{\circ} \mathrm{C}, 360 \mathrm{~kg} \mathrm{~m}^{-3}$, and $2110 \mathrm{~J} \mathrm{~kg}^{-1} \mathrm{~K}^{-1}$, respectively. MAR simulates an annual average $T_{\text {air }}$ of $-24^{\circ} \mathrm{C}$, and JJA average accumulation area surface skin temperature $\left(T_{\text {surface }}\right)$ is $-10^{\circ} \mathrm{C}$. The subsurface temperature should be between these two temperatures. GCNet observations confirm that the average temperature of the top snow layer is somewhat lower than $-10^{\circ} \mathrm{C}$ in the accumulation area during summer.

\subsection{Important role of NAO in 2000-2011 surface climate trends}

During summers 2007-2011, the JJA NAO index (data from http://www.cpc.ncep.noaa.gov/products/precip/CWlink/ pna/new.nao.shtml) has exhibited a persistent negative pattern, with anomalously high sea level pressure centered over Greenland. The 2011 summer average NAO index anomaly was $2.4 \sigma$ below the 1970-1999 average (Fig. 8). Consequently, the 2011 atmospheric flow was characterized by warm air advection from the south along the western ice sheet (Fig. 9). The persistence of this pattern 2007-2011 is without precedent in the period of record since 1950. The circulation anomaly led to more anticyclonic circulation, with less summer snowfall and larger $S \downarrow$ than normal over the southern portion of the ice sheet, allowing albedo to remain low during the peak $S \downarrow$ period of the summer. Under this circulation regime, numerous ice sheet melting records were set (Fettweis et al., 2011c).

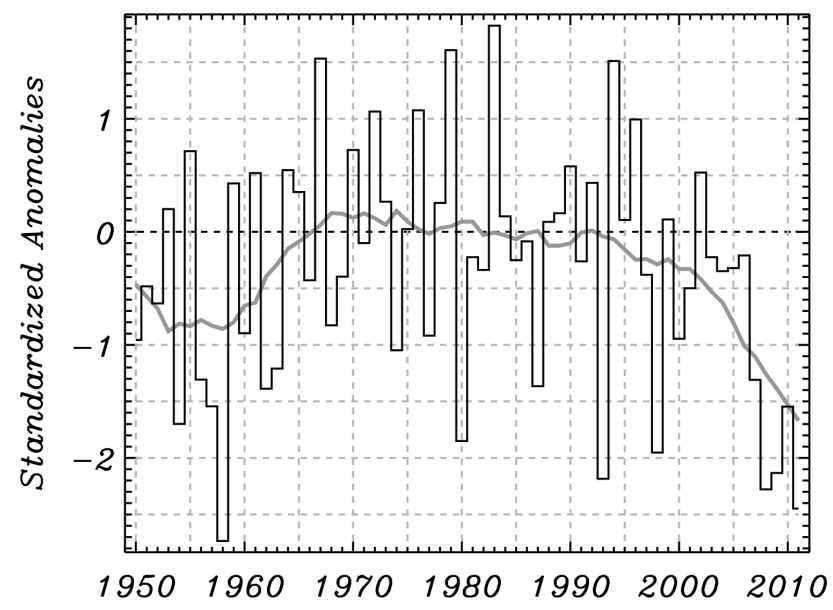

Fig. 8. Summer NAO index anomalies standardized relative to 1970-1999 baseline, indicating an anomalous and persistent negative pattern 2007-2011. The black bars indicate June-August averages of monthly anomalies. The grey line represents an 11-yr $4 \sigma$ Gaussian running average that becomes increasingly a leading (trailing) average as the beginning (end) point of the time series is reached, respectively.

The MAR simulations reveal a set of inter-related and statistically significant ice sheet surface climate trends in the 2000-2011 period occurring in response to the persistent anomalous circulation (Fig. 9). Over both the ablation and accumulation areas, $S \downarrow, T_{\text {air }}$, and $S_{\text {net }}$ and thus melting increased significantly in response to significant decreases 
Table 2. Ice sheet summer (June-August) surface climate variability 2000-2011 from the MAR regional climate model and MODIS MOD10A1 data partitioned among ablation and accumulation areas by annual surface mass balance.

\begin{tabular}{|c|c|c|c|c|c|c|c|}
\hline \multirow[b]{2}{*}{ Parameter } & \multirow[b]{2}{*}{ Units } & \multicolumn{3}{|c|}{ Ablation Area } & \multicolumn{3}{|c|}{ Accumulation Area } \\
\hline & & Average & $\begin{array}{r}\text { Linear change } \\
\text { of average }\end{array}$ & $\begin{array}{l}\text { St. dev. } \\
\text { residuals }\end{array}$ & Average & $\begin{array}{r}\text { Linear change } \\
\text { of average }\end{array}$ & $\begin{array}{r}\text { St. dev. } \\
\text { residuals }\end{array}$ \\
\hline$T_{\text {air }}$ & ${ }^{\circ} \mathrm{C}$ & -1.6 & 0.5 & 0.4 & -8.8 & 0.5 & 0.5 \\
\hline Snow & mm w.e. & 15.9 & -6.9 & 2.1 & 28.2 & -7.3 & 3.4 \\
\hline Rain & mm w.e. & 39.3 & -10.4 & 10.4 & 6.0 & -2 & 1.5 \\
\hline Rain/Snow & none & 2.5 & 0.4 & 0.7 & 0.2 & 0.0 & 0.0 \\
\hline$S \downarrow$ & $\mathrm{W} \mathrm{m}^{-2}$ & 280.9 & 5.4 & 3.8 & 296.3 & 3.4 & 3.0 \\
\hline$S_{\text {net }}$ & $\mathrm{W} \mathrm{m}{ }^{-2}$ & 110.8 & 11.0 & 7.4 & 60.5 & 2.3 & 1.6 \\
\hline$L \downarrow$ & $\mathrm{W} \mathrm{m}^{-2}$ & 242.1 & -1.3 & 3.5 & 209.4 & 0.6 & 4.1 \\
\hline$L_{\text {net }}$ & $\mathrm{W} \mathrm{m}^{-2}$ & -64.6 & -2.7 & 3.1 & -61.0 & -1.5 & 2.1 \\
\hline$S \downarrow+L \downarrow$ & $\mathrm{W} \mathrm{m}^{-2}$ & 523.0 & 4.2 & 1.5 & 505.8 & 4.0 & 1.9 \\
\hline$R_{\text {net }}$ & $\mathrm{W} \mathrm{m}^{-2}$ & 46.2 & 8.3 & 6.2 & -0.5 & 0.8 & 0.7 \\
\hline$Q_{\mathrm{SH}}$ & $\mathrm{W} \mathrm{m}^{-2}$ & 17.7 & 3.2 & 2.1 & 5.0 & 0.1 & 0.5 \\
\hline$Q_{\mathrm{LH}}$ & $\mathrm{W} \mathrm{m}^{-2}$ & -4.5 & 0.3 & 0.8 & -0.6 & 0.1 & 0.2 \\
\hline$Q_{\mathrm{SH}}+Q_{\mathrm{LH}}$ & $\mathrm{W} \mathrm{m}^{-2}$ & 13.1 & 3.4 & 1.9 & 4.4 & 0.2 & 0.4 \\
\hline$\alpha_{\mathrm{MOD} 10 \mathrm{~A} 1}$ & none & 0.673 & -0.091 & 0.021 & 0.809 & -0.046 & 0.006 \\
\hline Melt & mm w.e. & 1257.9 & 261.5 & 158.0 & 123.9 & 18.1 & 18.2 \\
\hline
\end{tabular}

in snowfall and albedo (Table 2). The $S \downarrow$ increase is consistent with the $L \downarrow$ decrease given their highly significant $(1-p=0.999)$ inverse correlation $(-0.845)$. The sum of $L \downarrow$ and $S \downarrow,\left(R_{\text {net }}\right)$ increased. $Q_{\mathrm{SH}}$ increased while less negative $Q_{\mathrm{LH}}$ indicates less evaporative heat sink. The ratio of rain to snow increased over the ablation area, though not larger than $1 \sigma$ of the regression residuals.

The signal of increased snowfall with increasing $T_{\text {air }}$ over the accumulation area (Fig. 10a) is related to climatic warming enhancement of ocean evaporation and moisture carrying capacity of the air, leading to higher moisture transport inland over the ice sheet and, consequently, higher precipitation (Fettweis et al., 2011b). The relative dominance of cyclonic or anticyclonic conditions impacts the precipitation amount independently of temperature. Over the ablation area, there is a negative correlation between snowfall and $T_{\text {air }}$ anomalies, because MAR simulates more of the precipitation falling as rain instead of snow in relatively warm summers. Similar to the positive $T_{\text {air }}$ correlation with snowfall (Fig. 10a), warm years are associated with more rainfall over the ice sheet. Rainfall is confirmed to occur on the ice sheet. Using a Nipher shielded gauge, J. Box measured $5 \mathrm{~cm}$ rainfall in a single $24 \mathrm{~h}$ period in June 1998 at Swiss Camp located at $1150 \mathrm{~m}$ along the western slope of the ice sheet. The signal of increased rainfall with increasing $T_{\text {air }}$ is expected because, as air warms, the fraction of precipitation falling as rain will increase (Fig. 10b). MAR simulations reveal the important role of summer snowfall on increasing surface albedo over the ablation area (Fig. 11a). Note positive correlation dominating in the ablation area. Thus, especially in 2009 2011 summers, modulated by persistent negative NAO index

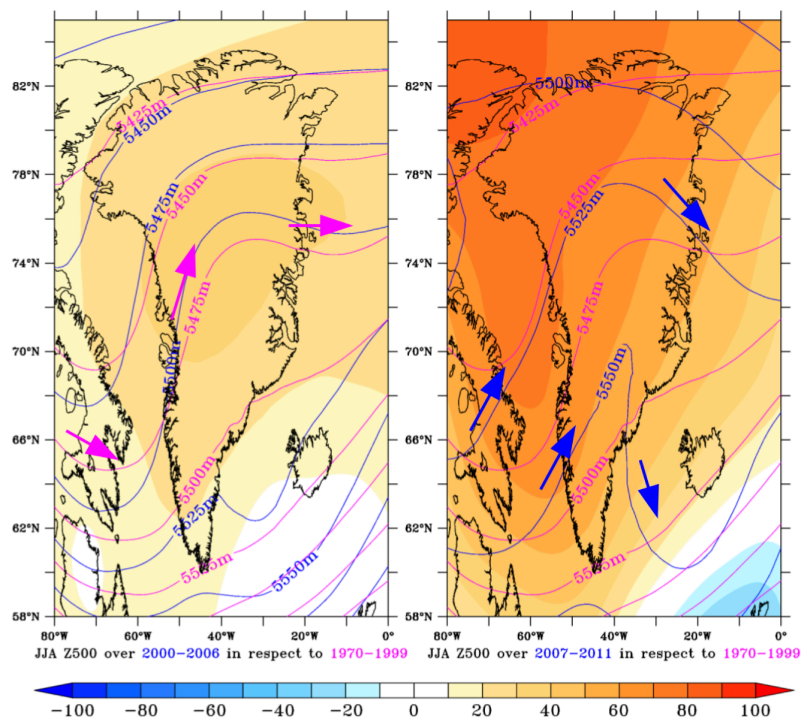

Fig. 9. The geopotential height anomalies for JJA 2000-2006 (a) and 2007-2011 (b) (referenced to the 1970-1999 average) at $500 \mathrm{hPa}$ from the NCEP/NCAR Reanalysis. The blue and respectively magenta lines illustrate the JJA average geopotential height at $500 \mathrm{hPa}$ in 2000-2006 and 2007-2011 and over 1970-1999. The arrows show the direction of the prevailing flow.

(inducing dominance of anticyclonic conditions), the albedo feedback could be maximized. 

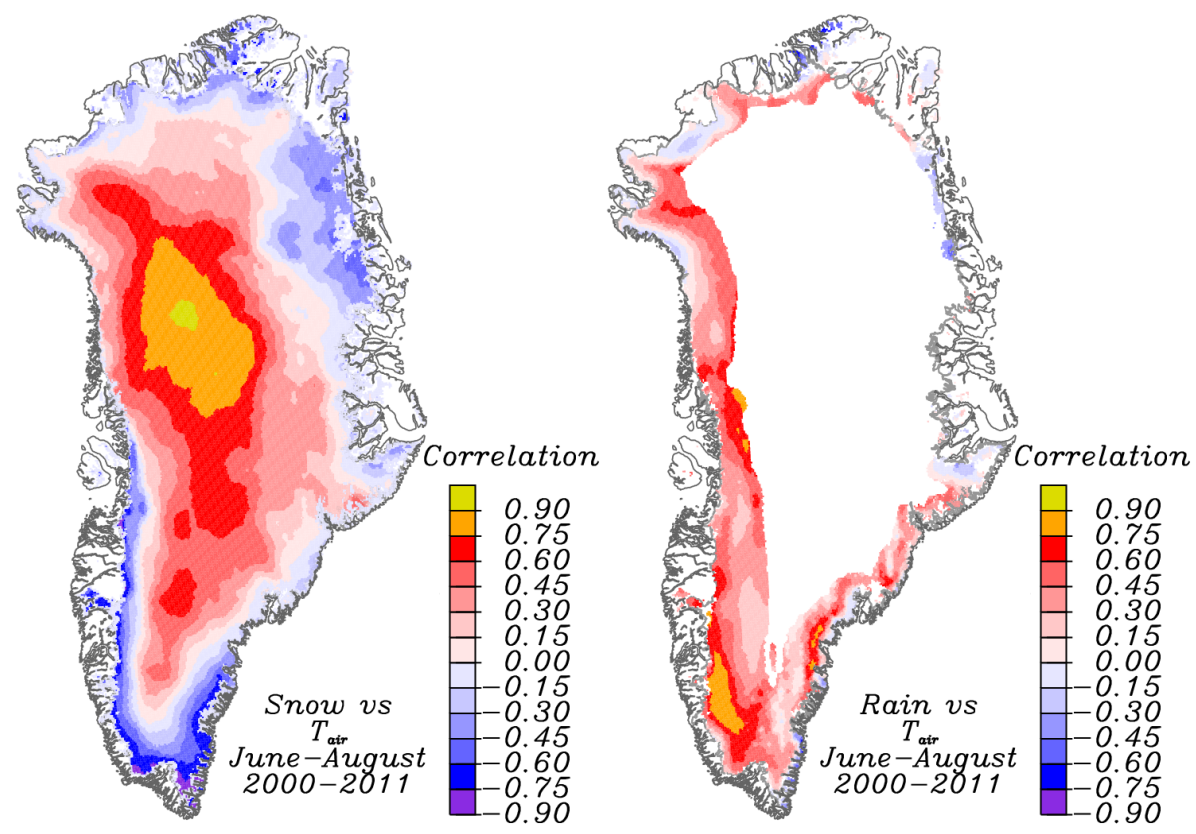

Fig. 10. (a) Summer (June-August) spatial patterns of the correlation between $5 \mathrm{~km}$ resampled MAR snowfall and $3 \mathrm{~m}$ surface air temperature data. (b) Same as left but with MAR rainfall instead of snowfall. Values where simulated rainfall is less than $5 \mathrm{~mm}$ are excluded, because in this limit the values are highly uncertain. The regression variables are first temporally detrended to minimize spurious correlation.
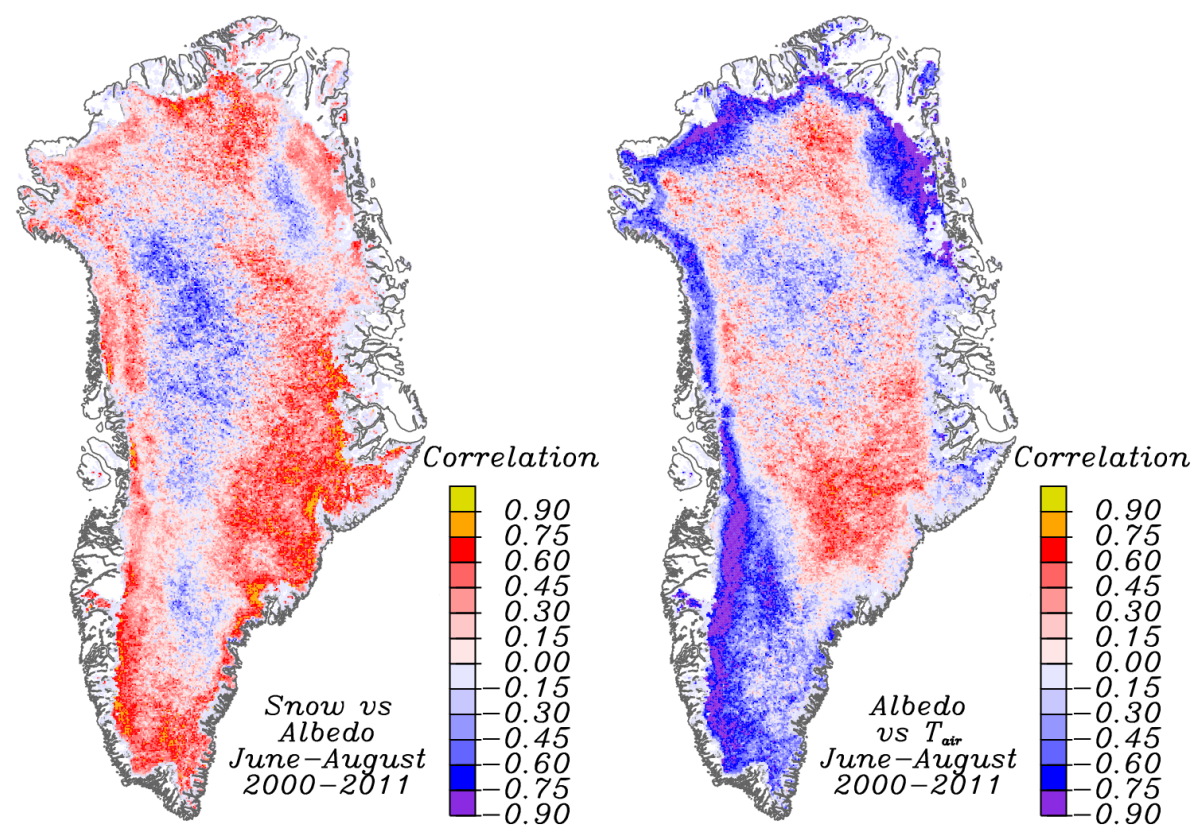

Fig. 11. (a) Summer (June-August) spatial patterns of the correlation between $5 \mathrm{~km}$ averaged MODIS MOD10A1 albedo and $25 \mathrm{~km}$ averaged MAR snowfall data. (b) Summer (June-August) spatial patterns of the correlation between 5km averaged MODIS MOD10A1 albedo and 25 km averaged MAR MAR $T_{\text {air }}$ data. 


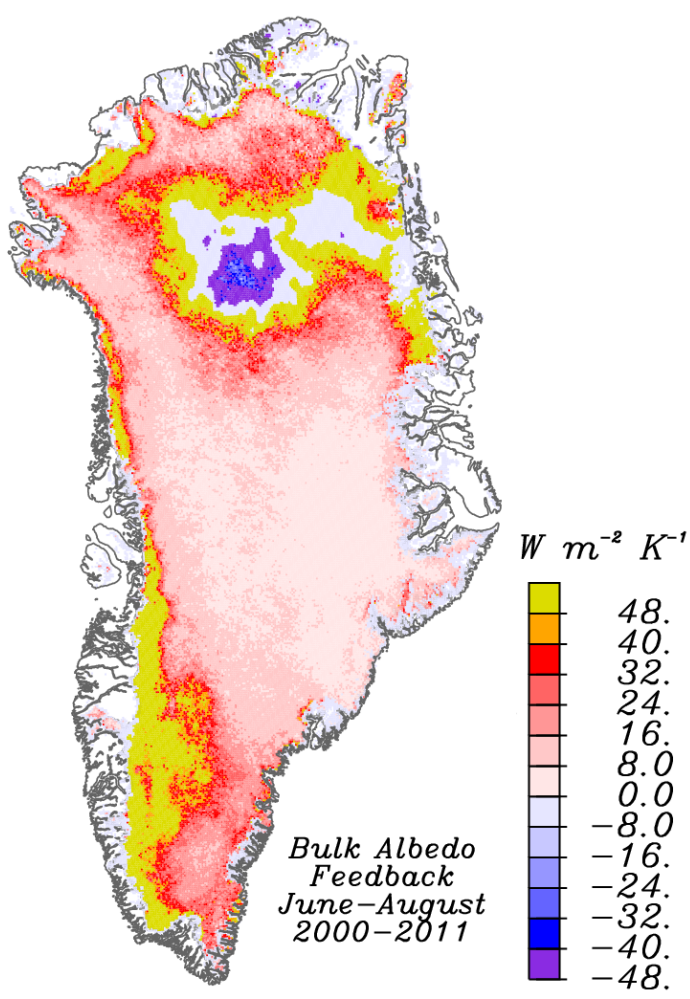

Fig. 12. Summer (JJA) spatial patterns of bulk albedo feedback defined by the temporal trend in $\Delta S_{\text {net }} / \Delta T_{\text {air }}$ using MODIS MOD10A1 albedo data and calibrated MAR simulations of $S \downarrow$ and $T_{\text {air }}$.

\subsection{Ice sheet albedo sensitivity to surface air temperature}

Bulk albedo feedback is positive over $96 \%$ of the ice sheet and concentrated in the ablation area (Fig. 12) where the albedo decline is greatest (Fig. 7a). The bulk feedback calculation blows up where $\Delta T_{\text {air }}$ approaches zero. Negative $\alpha_{\text {feedback,b }}$ is where $\Delta T_{\text {air }}$ is negative. While $\alpha_{\text {feedback,b }}$ is useful to illustrate the long-term change in net shortwave flux versus $T_{\text {air }}$, the alternative formulation that uses paired interannual anomalies (see Fig. 5) reveals an interplay of physical mechanisms.

Over of the ablation area, the 2000-2011 albedo anomalies exhibit a negative correlation with the $T_{\text {air }}$ anomalies (Fig. 11b), suggesting that, in anomalously warm period years, the ice sheet albedo is anomalously low. In contrast, a positive correlation is evident over much of the higher elevation accumulation area, suggesting that, during anomalously warm periods, the albedo increases. While a positive $\alpha^{*}$ may be counterintuitive, its realism as a second-order process is consistent with the positive correlation signal between anomalies in $T_{\text {air }}$ and snowfall (Fig. 10a).

Negative albedo sensitivity is concentrated over the ablation area (Fig. 13a). The strongest negative $\alpha^{*}$ (albedo darkening sensitivity to $T_{\text {air }}$ ), between $-11 \% \mathrm{~K}^{-1}$ and $-15 \% \mathrm{~K}^{-1}$, is found along the southwestern ablation area, immediately below the equilibrium line altitude observed to be $\sim 1450 \mathrm{~m}$ (van de Wal et al., 2005) where the seasonal snow cover, once ablated, reveals a darker underlying bare and often impurity-rich (Wientjes and Oerlemans, 2010) solid ice surface. Areas of negative $\alpha^{*}$ are widespread with trends at or above $80 \%$ confidence. Consistent with findings for the terrestrial environment (Qu and Hall, 2007), the strength of albedo feedback is determined more by the surface albedo decrease associated with a loss of seasonal snow cover than the reduction in snow albedo due to snow metamorphosis because of the large difference between snow and bare ice albedo values.

The opposite pattern, positive $\alpha^{*}$, is found over $46 \%$ of the accumulation area (pink or red areas in Fig. 13a) (see also Fig. $11 \mathrm{~b}$ pink and red areas), indicating that the accumulation area gains in brightness in warmer years. Again, the positive albedo correlation with $T_{\text {air }}$, while counterintuitive, as a second-order process is consistent with a MAR-simulated increased snowfall in anomalously warm summers (Fig. 10a). Positive $\alpha^{*}$ that exceeds $80 \%$ confidence occurs over $11 \%$ of the accumulation area. At or above $95 \%$ confidence, that area fraction is $3 \%$. Peak positive $\alpha^{*}\left(+0.05 \% \mathrm{~K}^{-1}\right)$ is found on the central eastern ice sheet (coordinates: $66.6^{\circ} \mathrm{N}, 35.6^{\circ} \mathrm{W}$ ) at $\sim 1530$ m elevation.

When MAR $T_{\text {air }}$ are replaced with clear-sky retrieved MODIS MOD11A1 $T_{\text {surface, }}$, the positive (and negative) $\alpha^{*}$ regions are of smaller magnitude. Though $22 \%$ of the accumulation area still registers positive $\alpha^{*}$ values, the high uncertainty of the associated shallow trend is necessary to acknowledge. Using $T_{\text {surface }}$, only $5 \%$ of the accumulation area has $\alpha^{*}$ values above $+0.3 \% \mathrm{~K}^{-1}$. For two reasons, $T_{\text {surface }}$ is less sensitive to positive thermal perturbations than the allsky $T_{\text {air }}$ data: (1) $T_{\text {surface }}$ variability near and above $0{ }^{\circ} \mathrm{C}$ is capped by the latent heat sink of melting; and (2) comparisons with GC-Net AWS indicate that MODIS MOD11A1 $T_{\text {surface }}$ is consistently lower than $T_{\text {air }} . T_{\text {surface }}$ is more representative of cold perturbations to the surface, because, when $T_{\text {surface }}$ is retrieved by MODIS, the sky must be clear. Clear sky conditions are more often associated with surface radiative cooling than all-sky conditions. Using MAR $T_{\text {air }}$ instead of the $T_{\text {surface, }}$, roughly twice, or $46 \%$ (25\%) of the accumulation area, registers values above $0.0 \% \mathrm{~K}^{-1}\left(+0.3 \% \mathrm{~K}^{-1}\right)$, respectively.

In the lowest $\sim 600 \mathrm{~m}$ elevation of the southwestern ablation area, $\alpha^{*}$ is less because the glacier ice surface is already somewhat exposed at melt onset, because snow cover is thin $(<0.3 \mathrm{~m})$ (van den Broeke et al., 2008). Further, for an unknown reason, unlike the mid to upper ablation area, impurities concentrate below the surface in the lower ablation area (Wientjes and Oerlemans, 2010). Consequently, the lowest quarter of the ablation area does not produce as large an albedo change from pre-melt to mid-summer when snow cover is completely ablated. 

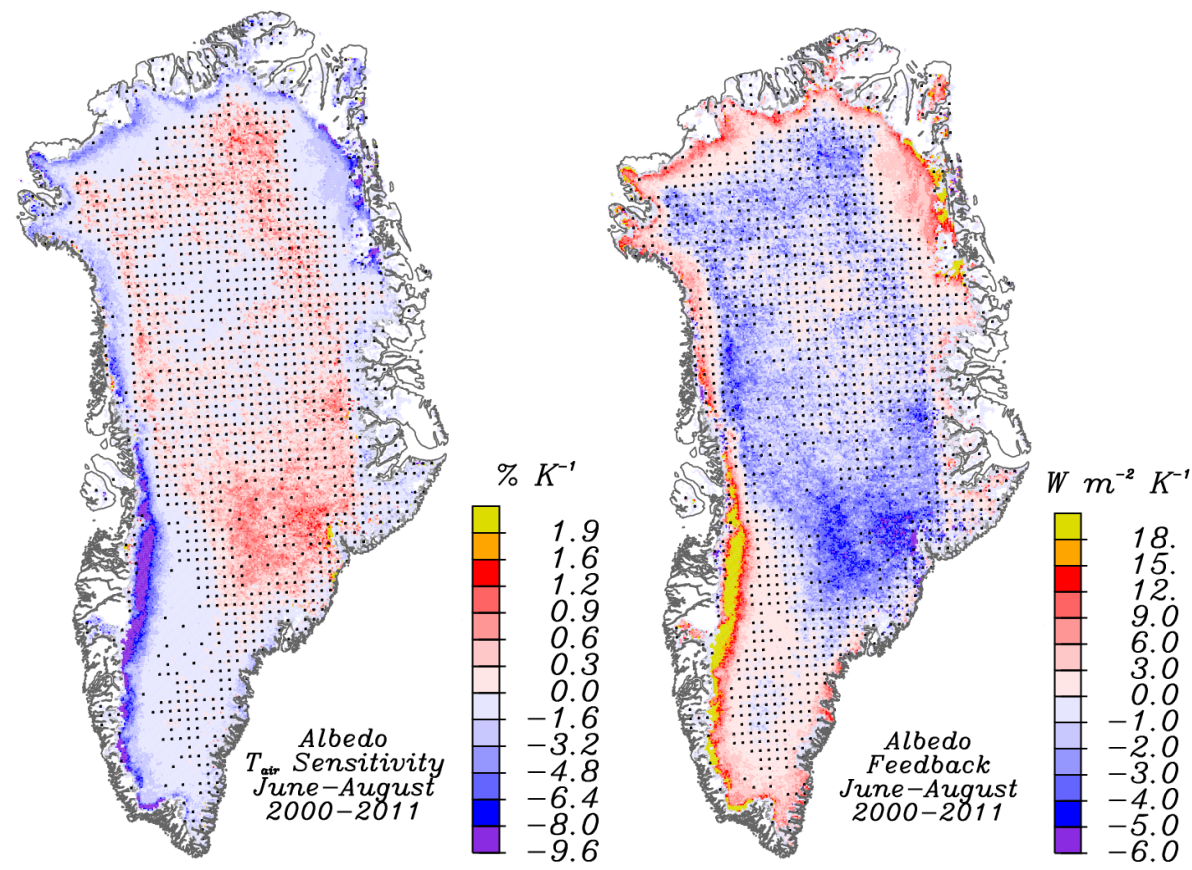

Fig. 13. (a) Summer (JJA) spatial patterns of MODIS MOD10A1 albedo sensitivity to the MAR-simulated surface air temperature. The positive scale is one-fifth that of the negative scale. (b) Summer spatial patterns of ice sheet albedo feedback based on MODIS albedo observations and calibrated MAR simulations of $S \downarrow$, and $T_{\text {air }}$. The negative albedo feedback scale is one-third that of the positive scale. The regressions are detrended to minimize spurious correlation. Stippled areas have trends that are not statistically significant above $80 \%$ confidence.

Averaged over the ablation area, $\alpha^{*}$ is $-3.4 \% \mathrm{~K}^{-1}$ (Table 3). Over the accumulation area, $\alpha^{*}$ averages $-0.2 \% \mathrm{~K}^{-1}$. Over the upper accumulation area, defined where elevation exceeds $2500 \mathrm{~m}, \alpha^{*}$ averages a slightly positive value, $+0.2 \% \mathrm{~K}^{-1}$.

\subsection{Ice sheet albedo feedback}

The June-August ice sheet albedo feedback with $T_{\text {air }}$ and $S \downarrow$ is positive over the ice sheet ablation area (Fig. 13b). Peak anomaly-derived feedback values of above $+45 \mathrm{~W} \mathrm{~m}^{-2} \mathrm{~K}^{-1}$ occur in the darkest parts of the ablation area, where surface concentration of impurities is greatest and the earlier ablation of winter snow produces a maximum albedo reduction. Averaged regionally, the southwestern ice sheet has median $\alpha_{\text {feedback,a }}$ values peaking at $+25 \mathrm{~W} \mathrm{~m}^{-2} \mathrm{~K}^{-1}$ at an elevation of $1250 \mathrm{~m}$. Averaged over the ablation area, $\alpha_{\text {feedback,a }}$ is $+8.3 \mathrm{~W} \mathrm{~m}^{-2} \mathrm{~K}^{-1}$ (Table 3). Over the accumulation area, $\alpha_{\text {feedback,a }}$ is slightly negative on average $\left(-0.4 \mathrm{~W} \mathrm{~m}^{-2} \mathrm{~K}^{-1}\right)$ (Table 3 ). The negative feedback signal is stronger $\left(-1.4 \mathrm{~W} \mathrm{~m}^{-2} \mathrm{~K}^{-1}\right)$ above $2500 \mathrm{~m}$ elevation in the "dry snow zone". Negative albedo feedback that exceeds $80 \%$ confidence occurs over $26 \%$ of the accumulation area. At or above $95 \%$ confidence, that area fraction is $9 \%$. Given that this fraction exceeds the statistical Type-1 error margin $(20 \%$ or $5 \%$, respectively), by nearly a factor of 2 in the case of the trends at $95 \%$ confidence, the con-
Table 3. Magnitude of albedo-temperature sensitivity and net shortwave flux (insolation) feedback for different ice sheet surface mass balance regions.

\begin{tabular}{llrrl}
\hline Metric & $\begin{array}{c}\text { Abl. } \\
\text { area }\end{array}$ & $\begin{array}{r}\text { Accum. } \\
\text { area }\end{array}$ & $\begin{array}{r}\text { Accum. area, } \\
\text { above } 2500 \mathrm{~m} \text { Units }\end{array}$ \\
\hline$\alpha_{*}$ & -3.4 & -0.2 & +0.2 & $\% \mathrm{~K}^{-1}$ \\
$\alpha_{\text {feedback, a }}$ & +8.3 & -0.4 & -1.4 & $\mathrm{~W} \mathrm{~m}^{-2} \mathrm{~K}^{-1}$ \\
$\alpha_{\text {feedback,b }}$ & +50.1 & +18.2 & +10.4 & $\mathrm{~W} \mathrm{~m}^{-2} \mathrm{~K}^{-1}$ \\
\hline
\end{tabular}

clusion of statistically significant association is robust, albeit over $9 \%$ of the accumulation area. Peak negative feedback $\left(-15 \mathrm{~W} \mathrm{~m}^{-2} \mathrm{~K}^{-1}\right)$ occurs at the same position as the peak positive $\alpha^{*}$.

Averaged over the ice sheet, the transition from positive to negative albedo feedback occurs at an elevation of $1500 \mathrm{~m}$. Positive (negative) feedback is not confined exclusively to the (accumulation) ablation area, respectively. Rather, the regimes overlap in elevation (Fig. 14). 


\section{Conclusions}

\subsection{MAR accuracy}

The observationally constrained MAR simulations compare favorably with surface observations from AWS with RMS error values for downward solar irradiance of $5 \%$ and $1{ }^{\circ} \mathrm{C}$ for surface air temperature, respectively. High correlation with the AWS data at monthly time scale justified applying regression-based calibrations to improve the absolute accuracy of the MAR data.

\subsection{MAR climate insights}

After a small calibration based on GC-Net AWS data, summer average $T_{\text {air }}$ over the ablation and accumulation areas increased significantly, by $0.5^{\circ} \mathrm{C}$. Meanwhile, $S \downarrow$ also increased significantly over the much of the ice sheet. The rain to snowfall ratio increased over the ablation area.

\subsection{Albedo data validation}

According to a cross validation with independent GC-Net AWS data, degrading MODIS instrument sensitivity identified by Wang et al. (2012) is not here detected in the MOD10A1 product.

Analysis of the AWS data reveals declining albedo trends in the 2000-2010 period to be widespread in individual months from May-September. In 41 of 43 (95\%) of monthly cases May-September, a decreasing trend is found to exceed $2 \sigma$ of the regression residuals. In 10 of $14(71 \%)$ cases for which both GC-Net and MOD10A1 trends are significant, the GC-Net declining trend is even larger than the MOD10A1 trend.

We have thus ruled out that degradation of the GC-Net photoelectric diode pyranometers produces an erroneous declining albedo trend.

The coherent interannual variability evident in the correlation between synchronous GC-Net and MOD10A1 data suggests that at monthly time scales both observations capture the same climate signal.

At the GC-Net Summit AWS where surface melting is not detected by passive microwave remote sensing, the declining albedo trend magnitudes among GC-Net and MOD10A1 results for individual months May-July are consistently negative.

Consistent with the MOD10A1 result, the largest magnitude declining albedo trends are evident at the sites located in the ablation zone such as JAR1 and Swiss Camp. Similarly consistent among these independent albedo change results, declining albedo trends are observed consistently in individual months at the more southerly yet relatively high elevation sites of Saddle and South Dome where melting is uncommon in passive microwave observations.

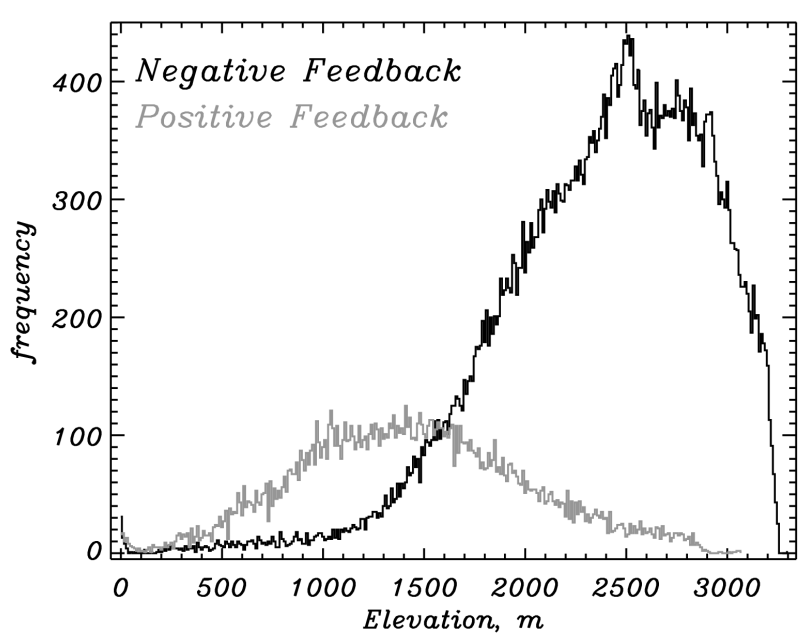

Fig. 14. Elevational histograms of temporally detrended albedo feedback for the whole ice sheet for $5 \mathrm{~km}$ grid cells used in this study.

\subsection{Albedo decline}

MODIS MOD10A1 albedo data indicate a significant ice sheet areal-averaged albedo decline $(-0.056 \pm 0.007)$ in the June-August period over the 12 melt seasons spanning 2000-2011. The albedo decline is the largest in magnitude over the ablation area $(-0.091 \pm 0.021$ on average $)$ where bare ice area is increasingly exposed and earlier in the melt period after winter seasonal snow cover ablates reveal a darker glacier ice surface with abundant impurities. A significant albedo decline of $0.046 \pm 0.006$ in the $2000-2011$ period from a year 2000 value of 0.830 is observed for the accumulation area, where warming surface temperatures are enhancing snow grain metamorphosis. Reduced summer snowfall rates sustained low albedo, maximizing surface solar heating, progressively lowering albedo over multiple years. The albedo declines exceed the absolute RMS error found to be 0.041 using AWS data on the seasonal time scale.

Year 2011 albedo over the Greenland ice sheet is the lowest observed in the 12 years since MODIS observations began 5 March, 2000. As in year 2010, 2011 albedos are more than $1 \sigma$ below the 2000-2011 average.

\subsection{Albedo sensitivity to temperature}

Over the ablation area, the albedo sensitivity to surface air temperature reaches peak values of $-12 \% \mathrm{~K}^{-1}$ range over the southwestern ice sheet ablation area just below equilibrium line altitude at an elevation of $\sim 1350 \mathrm{~m}$. Temporally detrended albedo anomalies correlate positively and significantly with snowfall rates. Thus, higher ablation area albedo is associated, not surprisingly, with higher summer snowfall rates. 
When MODIS MOD11A1 land surface temperature data are used to evaluate temperature sensitivity, as an alternative to near-surface air temperature data from MAR, a weaker response is evident. Surface temperature variability represents relatively low surface and air temperature clear sky conditions. Further, surface temperature is capped near and above $0^{\circ} \mathrm{C}$. We thus conclude that surface temperature data are less desirable for the assessment of albedo sensitivity than all-sky near-surface air temperature data provided by in-situ observations or calibrated regional climate model output.

\subsection{Albedo feedback}

Downward solar irradiance combined with albedo temperature-sensitivity data provides a quantitative assessment of the albedo feedback that is intrinsic to the data.

Peak albedo feedback values are positive and prevail over the ablation area (values exceeding $+50 \mathrm{~W} \mathrm{~m}^{-2} \mathrm{~K}^{-1}$ ) where, for example, melt seasons marked by abnormally high air surface temperature are characterized by an earlier loss of high albedo cold season accumulated snow, exposing for a longer period a relatively dark and impurity rich bare ice surface, amplifying melt volume. Averaged over the ablation area, the feedback exhibits a value of $+8.3 \mathrm{~W} \mathrm{~m}^{-2} \mathrm{~K}^{-1}$ when defined using the regression of interannual paired albedo and net shortwave anomalies. Averaged over the accumulation area, the feedback exhibits a value of $+-0.4 \mathrm{~W} \mathrm{~m}^{-2} \mathrm{~K}^{-1}$.

When the feedback is defined using time series instead of interannual anomalies, an ablation area average of $+50.1 \mathrm{~W} \mathrm{~m}^{-2} \mathrm{~K}^{-1}$ is evident. By this bulk albedo feedback, the accumulation area average is $+18.2 \mathrm{~W} \mathrm{~m}^{-2} \mathrm{~K}^{-1}$. The more positive values are the result of this metric being less sensitive to the tendency of increased snowfall variability to limit absorbed solar radiation in anomalously warm years. This effect is pronounced over the upper accumulation area, a.k.a. the "dry snow zone", where negative feedback values exceeding $-10 \mathrm{~W} \mathrm{~m}^{-2} \mathrm{~K}^{-1}$ are evident. The bulk albedo feedback necessarily includes negative values where temperature trends are negative. The bulk albedo feedback should also be negative in situations where there is albedo increase in the presence of increasing temperature trend.

Evidence of a second-order accumulation area negative feedback is supported by observation of a positive correlation between snowfall and surface air temperature anomalies in this region. A tendency toward negative feedback indicates the damping effect of increased snowfall (increased albedo) on melt, ironically in anomalously warmer years that have higher precipitation potential from increased evaporation from oceans. As a result of surface brightening resulting from increased snowfall, the accumulation area negative albedo feedback is important in maintaining the ice sheet. Competing factors such as a more positive surface radiation balance or increased sensible heat import by advection eventually will overwhelm the negative albedo feedback's abil- ity to maintain sub-freezing temperatures. Indeed, during the period of this study, the surface radiation budget increased despite the damping effect of the negative feedback.

Positive albedo feedback prevailing over the ablation area accounts for more than half of the increased melt in that region in the last $2 \mathrm{yr}$ (2010 and 2011). However, without these two extreme years, it would not be clear whether albedo feedback played an increased role. What sets 2010 and 2011 apart from previous years is the albedo response to the combined effect of reduced summer snowfall and sensible heat import from warm air advection triggered by persistent anomalous atmospheric circulation.

The negative feedback we have identified is found in anomaly space. While there can be no doubt that the strong negative albedo sensitivity found in the ablation area, when combined with downward shortwave data, produces a high correlation and spatially coherent region of "positive feedback", the much shallower trend in the accumulation area is no doubt less intuitive. Yet, given the positive accumulation area correlation between snowfall and temperature, a physical mechanism is available to explain this second-order damping, without which complete melting over the entire ice sheet surface may already be observed. The significance testing yields some confidence that the second-order damping feedback evident over the accumulation area is real. The damping feedback is not preventing the accumulation area net radiation from approaching positive values. The accumulation area negative albedo anomaly feedback is clearly not strong enough to fully damp out the effects of warming. There is an overall albedo decline. Yet, hidden in the interannual anomalies is evidence of this damping feedback.

\subsection{Summer NAO importance}

A persistent negative summer NAO index in the 2000s has promoted along western Greenland a chain reaction of feedbacks. Three key mechanisms emerge that amplify melting: (1) increased warm (south) air advection along the western ice sheet increases downward sensible heating. In turn, snow metamorphism increases ice grain radii, reducing surface albedo. For areas where the surface is melting, increased liquid water content further reduces the albedo; (2) clear sky conditions favored by anomalously high surface pressure promote reduced cloudiness. In turn, diabatic heating by $S \downarrow$ is increased and (3) reduced summer snowfall precipitation promotes continued snow metamorphosis, keeping the surface in a darkened state and, in low accumulation areas, preconditioning the following melt season for enhanced melting. All three mechanisms work together in a complex feedback revealed by examination of surface energy budget shifts in response to atmospheric circulation. 


\subsection{Accumulation area radiation budget shift}

In the 12 yr beginning in 2000 , the reduced albedo combined with a significant increase in downward solar irradiance yielded an accumulation area net radiation increase from -0.9 to $-0.2 \mathrm{~W} \mathrm{~m}^{-2}$. Another similar decade may be sufficient to shift the average summer accumulation area radiation budget from negative to positive, resulting in an abrupt ice sheet melt area increase. The ice sheet mass budget deficit is therefore expected to become more sensitive to increasing temperatures via the ice albedo feedback, especially in negative summer NAO index conditions. Future work should therefore be concerned with understanding potential tipping points in ice sheet melt regime as the average radiation budget shifts from negative (cooling) to positive (heating), as it seems the threshold of this has just been reached. It will take some time, perhaps years, for the cold content of the firn to be sufficiently eroded to allow continuous summer melting and an ice sheet surface characterized by $100 \%$ melt extent. Further warming would only hasten the amplification of melting that the albedo feedback permits.

\section{Supplementary material related to this article is available online at: http://www.the-cryosphere.net/6/821/ 2012/tc-6-821-2012-supplement.pdf.}

Acknowledgements. Research at The Ohio State University was supported by its Climate Water and Carbon initiative managed by D. Alsdorf. D. Decker and R. Benson gathered the MOD10A1 data. N. E. DiGirolamo (SSAI \& NASA GSFC) provided data tile stitching insight. K. Steffen supported the transport of the Nipher shielded precipitation gauge to/from Swiss Camp. N. Steiner provided insight into passive microwave melt days retrievals and assisted in citation database management in early versions of this manuscript. This is Byrd Polar Research Center contribution number 1420. Research at the City College of New york was supported by the NASA Cryospheric Program and the NSF grant ARC 0909388. We are grateful to reviewers for constructive comments.

Edited by: M. Van den Broeke

\section{References}

Abdalati, W. and Steffen, K..: Greenland ice sheet melt extent: 1979-1999, J. Geophys. Res.-Atmos., 106, 33983-33988, doi:10.1029/2001jd900181, 2001.

van As, D., Hubbard, A. L., Hasholt, B., Mikkelsen, A. B., van den Broeke, M. R., and Fausto, R. S.: Large surface meltwater discharge from the Kangerlussuaq sector of the Greenland ice sheet during the record-warm year 2010 explained by detailed energy balance observations, The Cryosphere, 6, 199-209, doi:10.5194/tc-6-199-2012, 2012.
Bamber, J. L., Layberry, R. L. and Gogineni, S.: A new ice thickness and bed data set for the Greenland ice sheet 1. Measurement, data reduction, and errors, J. Geophys. Res.-Atmos., 106, 33773 33780, doi:10.1029/2001jd900054, 2001.

Bøggild, C. E., Brandt, R. E., Brown, K. J., and Warren, S. G.: The ablation zone in Northeast Greenland: ice types, albedos and impurities, J. Glaciol., 56, 101-113, 2010.

Box, J. E.: Polar day effective cloud opacity in the Arctic from measured and modeled solar radiation fluxes, MA thesis, University of Colorado, Boulder, Colorado, 1997.

Box, J. E., Bromwich, D. H., Veenhuis, B. A., Bai, L.-S., Stroeve, J. C., Rogers, J. C., and Wang, S.-H.: Greenland ice sheet surface mass balance variability (1988-2004) from calibrated polar MM5 output, J. Climate, 19(12), 2783-2800, doi:10.1175/jcli3738.1, 2006.

van den Broeke, M., van As, D., Reijmer, C., and van de Wal, R.: Assessing and improving the quality of unattended radiation observations in Antarctica, J. Atmos. Ocean. Tech., 21, 1417-1431, doi:10.1175/1520-0426(2004)021<1417:aaitqo > 2.0.co;2, 2004.

van den Broeke, M., Smeets, P., Ettema, J., van der Veen, C., van de Wal, R., and Oerlemans, J.: Partitioning of melt energy and meltwater fluxes in the ablation zone of the west Greenland ice sheet, The Cryosphere, 2, 179-189, doi:10.5194/tc-2179-2008, 2008

van den Broeke, M., Bamber, J., Ettema, J., Rignot, E., Schrama, E., van de Berg, W. J., and Wouters, B.: Partitioning recent Greenland mass loss, Science, 326, 984-986, doi:10.1126/science.1178176, 2009.

van den Broeke, M. R., Smeets, C. J. P. P., and van de Wal, R. S. W.: The seasonal cycle and interannual variability of surface energy balance and melt in the ablation zone of the west Greenland ice sheet, The Cryosphere, 5, 377-390, doi:10.5194/tc-5-377-2011, 2011.

Chang, A. T. C., Gloersen, P., Schmugge, T., Wilheit, T. T., and Zwally, H. J.: Microwave emission from snow and glacier ice, J. Glaciol., 16, 23-39, 1976.

Chen, J. L., Wilson, C. R., and Tapley, B. D.: Interannual variability of Greenland ice losses from satellite gravimetry, J. Geophys. Res.-Sol. Ea., 116, B07406, doi:10.1029/2010jb007789, 2011.

Cuffey, K. M. and Paterson, W.: The physics of glaciers, Elsevier, 693 pp., 2010.

Dee, D. P., Uppala, S. M., Simmons, A. J., Berrisford, P., Poli, P. , Kobayashi, S., Andrae, U., Balmaseda, M. A., Balsamo, G., Bauer, P., Bechtold, P., Beljaars, A. C. M., van de Berg, L., Bidlot, J., Bormann, N., Delsol, C., Dragani, R., Fuentes, M., Geer, A. J., Haimberger, L., Healy, S. B., Hersbach, H., Hólm, E. V., Isaksen, L., Kållberg, P., Köhler, M., Matricardi, M., McNally, A. P., Monge-Sanz, B. M., Morcrette, J.-J., Park, B.-K., Peubey, C., de Rosnay, P., Tavolato, C., Thépaut, J.-N., and Vitart, F.: The ERA-Interim reanalysis: configuration and performance of the data assimilation system, Q. J. Roy. Meteor. Soc., 137, 553-597, doi:10.1002/qj.828, 2011.

Dozier, J., Schneider, S. R., and McGinnis, D. F.: Effect of grainsize and snowpack water equivalence on visible and near-infrared satellite-observations of snow, Water Resour. Res., 17, 12131221, doi:10.1029/WR017i004p01213, 1981.

Ettema, J., van den Broeke, M. R., van Meijgaard, E., van de Berg, W. J., Bamber, J. L., Box, J. E., and Bales, R. C.: Higher 
surface mass balance of the Greenland ice sheet revealed by highresolution climate modeling, Geophys. Res. Lett., 36, L12501, doi:10.1029/2009g1038110, 2009.

Fernandes, R., Zhao, H., Wang, X., Key, J., Qu, X., and Hall, A.: Controls on Northern Hemisphere snow albedo feedback quantified using satellite Earth observations, Geophys. Res. Lett., 36, L21702, doi:10.1029/2009g1040057, 2009.

Fettweis, X.: Reconstruction of the 1979-2006 Greenland ice sheet surface mass balance using the regional climate model MAR, The Cryosphere, 1, 21-40, doi:10.5194/tc-1-21-2007, 2007.

Fettweis, X., Gallée, H., Lefebre, F., and van Ypersele, J. P.: Greenland surface mass balance simulated by a regional climate model and comparison with satellite-derived data in 1990-1991, Clim. Dynam., 24, 623-640, doi:10.1007/s00382-005-0010-y, 2005.

Fettweis, X., Tedesco, M., van den Broeke, M., and Ettema, J.: Melting trends over the Greenland ice sheet (1958-2009) from spaceborne microwave data and regional climate models, The Cryosphere, 5, 359-375, doi:10.5194/tc-5-359-2011, $2011 \mathrm{a}$.

Fettweis, X., Belleflamme, A., Erpicum, M., Franco, B., and Nicolay, S.: Estimation of the sea level rise by 2100 resulting from changes in the surface mass balance of the Greenland ice sheet, in: Climate Change - Geophysical Foundations and Ecological Effects, edited by: Blanco, J. and Kheradmand, H., ISBN 978953-307-419-1, Hard cover, 520 pp., 2011 b.

Fettweis, X., Mabille, G., Erpicum, M., Nicolay, S., and van den Broeke, M.: The 1958-2009 Greenland ice sheet surface melt and the mid-tropospheric atmospheric circulation, Clim. Dynam., 36, 139-159, doi:10.1007/s00382-010-0772-8, 2011c.

Flanner, M. G., Shell, K. M., Barlage, M., Perovich, D. K., and Tschudi, M. A.: Radiative forcing and albedo feedback from the Northern Hemisphere cryosphere between 1979 and 2008, Nat. Geosci., 4, 151-155, doi:10.1038/ngeo1062, 2011.

Franco, B., Fettweis, X., Lang, C., and Erpicum, M.: Impact of spatial resolution on the modelling of the Greenland ice sheet surface mass balance between 1990-2010, using the regional climate model MAR, The Cryosphere, 6, 695-711, doi:10.5194/tc6-695-2012, 2012.

Gallée, H. and Schayes, G.: Development of a three-dimensional meso-gamma primitive equation model: katabatic winds simulation in the area of Terra Nova Bay, Antarctica, Mon. Weather Rev., 122, 671-685, doi:10.1175/15200493(1994)122<0671:doatdm>2.0.co;2, 1994.

Hall, A.: The role of surface albedo feedback in climate, J. Climate, 17(7), 1550-1568, doi:10.1175/15200442(2004)017<1550:trosaf > 2.0.co;2, 2004.

Hall, D. K., Williams Jr., R. S., Luthcke, S. B., and Digirolamo, N. E.: Greenland ice sheet surface temperature, melt and mass loss: 2000-2006, J. Glaciol., 54, 81-93, doi:10.3189/002214308784409170, 2008.

Hall, D. K., Box, J. E., Casey, K., Hook, S. J., Shuman, C. A., and Steffen, K.: Comparison of satellite-derived and in-situ observations of ice and snow surface temperatures over Greenland, Remote Sens. Environ., 112, 3739-3749, doi:10.1016/j.rse.2008.05.007, 2008.

Hall, D. K., Riggs, G. A., and Salomonson, V. V.: MODIS/Terra Snow Cover Daily L3 Global $500 \mathrm{~m}$ Grid V004, January to March 2003, Digital media, updated daily. National Snow and Ice Data Center, Boulder, CO, USA, 2011.
Howat, I. M., Smith, B. E., Joughin, I., and Scambos, T. A.: Rates of Southeast Greenland ice volume loss from combined ICESat and ASTER observations, Geophys. Res. Lett., 35, L17505, doi:10.1029/2008g1034496, 2008.

Klein, A. G. and Barnett, A. C.: Validation of daily MODIS snow cover maps of the Upper Rio Grande River Basin for the 2000-2001 snow year, Remote Sens. Environ., 86, 162-176, doi:10.1016/s0034-4257(03)00097-x, 2003.

Klein, A. G. and Stroeve, J. C.: Development and validation of a snow albedo algorithm for the MODIS instrument, edited by: Winther, J. G. S. R., Ann. Glaciol., 34, 45-52, 2002.

Knap, W. H. and Oerlemans, J.: The surface albedo of the Greenland ice sheet: satellite-derived and in situ measurements in the Sondre Stromfjord area during the 1991 melt season, J. Glaciol., 42, 364-374, 1996.

Konzelmann, T. and Ohmura, A.: Radiative fluxes and their impact on the energy-balance of the Greenland ice-sheet, J. Glaciol., 41, 490-502, 1995.

Krabill, W., Hanna, E., Huybrechts, P., Abdalati, W., Cappelen, J., Csatho, B., and Yungel, J.: Greenland ice sheet: increased coastal thinning, Geophys. Res. Lett., 31, L24402, doi:10.1029/2004g1021533, 2004.

Lefebre, F., Gallée, H., van Ypersele, J. P., and Greuell, W.: Modeling of snow and ice melt at ETH Camp (West Greenland) a study of surface albedo, J. Geophys. Res.-Atmos., 108, 4231, doi:10.1029/2001jd001160, 2003.

Lefebre, F., Fettweis, X., Gallée, H., Van Ypersele, J. P., Marbaix, P., Greuell, W., and Calanca, P.: Evaluation of a highresolution regional climate simulation over Greenland, Clim. Dynam., 25, 99-116, doi:10.1007/s00382-005-0005-8, 2005.

Liang S., Stroeve, J., and Box, J. E.: Mapping daily snow/ice shortwave broadband albedo from Moderate Resolution Imaging Spectroradiometer (MODIS): The improved direct retrieval algorithm and validation with Greenland in situ measurement, J. Geophys. Res., 110, D10109, doi:10.1029/2004JD005493, 2005.

Mote, T. L.: Greenland surface melt trends 1973-2007: evidence of a large increase in 2007, Geophys. Res. Lett., 34, L22507, doi:10.1029/2007g1031976, 2007.

Mote, T. L. and Anderson, M. R.: Variations in snowpack melt on the Greenland ice sheet based on passive-microwave measurements, J. Glaciol., 41, 51-60, 1995.

Pritchard, H. D., Arthern, R. J., Vaughan, D. G., and Edwards, L. A.: Extensive dynamic thinning on the margins of the Greenland and Antarctic ice sheets, Nature, 461, 971-975, doi:10.1038/nature08471, 2009.

Qu, X. and Hall, A.: What controls the strength of snow-albedo feedback?, J. Climate, 20, 3971-3981, doi:10.1175/jcli4186.1, 2007.

Rignot, E. and Kanagaratnam, P.: Changes in the velocity structure of the Greenland ice sheet, Science, 311, 986-990, doi:10.1126/science.1121381, 2006.

Rignot, E., Box, J. E., Burgess, E., and Hanna, E.: Mass balance of the Greenland ice sheet from 1958 to 2007, Geophys. Res. Lett., 35, L20502, doi:10.1029/2008g1035417, 2008.

Rignot, E., Velicogna, I., van den Broeke, M. R., Monaghan, A., and Lenaerts, J.: Acceleration of the contribution of the Greenland and Antarctic ice sheets to sea level rise, Geophys. Res. Lett., 38, L05503, doi:10.1029/2011g1046583, 2011. 
Steffen, K., Box, J. E., and Abdalati W.: Greenland climate network: GCNet, US Army Cold Regions Reattach and Engineering (CRREL), CRREL Special Report, 98-103, 1996.

Stroeve, J.: Assessment of Greenland albedo variability from the advanced very high resolution radiometer Polar Pathfinder data set, J. Geophys. Res.-Atmos., 106, 33989-34006, doi:10.1029/2001jd900072, 2001.

Stroeve, J. C., Box, J. E., and Haran, T.: Evaluation of the MODIS (MOD10A1) daily snow albedo product over the Greenland ice sheet, Remote Sens. Environ., 105, 155-171, doi:10.1016/j.rse.2006.06.009, 2006.

Tedesco, M.: Snowmelt detection over the Greenland ice sheet from SSM/I brightness temperature daily variations, Geophys. Res. Lett., 34, L02504, doi:10.1029/2006g1028466, 2007.

Tedesco, M., Fettweis, X., van den Broeke, M. R., van de Wal, R. S. W., Smeets, C. J. P. P., van de Berg, W. J., Serreze, M. C., and Box, J. E.: The role of albedo and accumulation in the 2010 melting record in Greenland, Environ. Res. Lett., 6, 014005, doi:10.1088/1748-9326/6/1/014005, 2011.

van de Wal, R. S. W., Greuell, W., van den Broeke, M. R., Reijmer, C. H., and Oerlemans, J.: Surface mass-balance observations and automatic weather station data along a transect near Kangerlussuaq, West Greenland, edited by: Dowdeswell, J. and Willis, I. C., Ann. Glaciol., 42, 311-316, 2005.
Wan, Z. M., Zhang, Y. L., Zhang, Q. C., and Li, Z. L.: Validation of the land-surface temperature products retrieved from Terra Moderate Resolution Imaging Spectroradiometer data, Remote Sens. Environ., 83, 163-180, doi:10.1016/s0034-4257(02)00093-7, 2005.

Wan, Z. M.: New refinements and validation of the MODIS LandSurface Temperature/Emissivity products, Remote Sens. Environ., 112, 59-74, doi:10.1016/j.rse.2006.06.026, 2008.

Wang, D., Morton, D., Masek, J., Wu, A., Nagol, J., Xiong, X., Levy, R., Vermote, E., and Wolfe, R.,: Impact of sensor degradation on the MODIS NDVI time series, Remote Sens. Environ., 119, 55-61, doi:10.1016/j.rse.2011.12.001, 2011.

Warren, S. G.: Optical-properties of snow, Rev. Geophys., 20, 6789, doi:10.1029/RG020i001p00067, 1982.

Wientjes, I. G. M. and Oerlemans, J.: An explanation for the dark region in the western melt zone of the Greenland ice sheet, The Cryosphere, 4, 261-268, doi:10.5194/tc-4-261-2010, 2010.

Wiscombe, W. J. and Warren, S. G.: A Model for the spectral albedo of snow, 1. Pure snow, J. Atmos. Sci., 37, 2712-2733, doi:10.1175/1520-0469(1980)037<2712:amftsa $>2.0 . c o ; 2$, 1980 . 